\title{
ELECTIONS AND THE QUALITY OF PUBLIC OFFICIALS: EVIDENCE FROM U.S. STATE COURTS
}

\author{
Claire S.H. Lim \\ James M. Snyder, Jr. \\ Working Paper 18355 \\ http://www.nber.org/papers/w18355 \\ NATIONAL BUREAU OF ECONOMIC RESEARCH \\ 1050 Massachusetts Avenue \\ Cambridge, MA 02138 \\ September 2012
}

The research conducted for this article was supported by a research grant from the American Bar Association (ABA) Section of Litigation; however, the views expressed here are not intended to represent ABA positions or policies. The views expressed herein are those of the authors and do not necessarily reflect the views of the National Bureau of Economic Research.

NBER working papers are circulated for discussion and comment purposes. They have not been peerreviewed or been subject to the review by the NBER Board of Directors that accompanies official NBER publications.

(C) 2012 by Claire S.H. Lim and James M. Snyder, Jr.. All rights reserved. Short sections of text, not to exceed two paragraphs, may be quoted without explicit permission provided that full credit, including (C) notice, is given to the source. 
Elections and the Quality of Public Officials: Evidence from U.S. State Courts

Claire S.H. Lim and James M. Snyder, Jr.

NBER Working Paper No. 18355

September 2012

JEL No. D72,D78,H70,K40

\begin{abstract}
$\underline{\text { ABSTRACT }}$
We investigate the influence of electoral rules and voter information in elections on voting outcomes and the quality of public officials, using new data on state court judge elections in 39 states in the U.S. from 1990 to 2010 . We find, first, that voting is very partisan in partisan judicial elections - i.e., there is a strong correlation between the Democratic "normal vote" and the Democratic vote share for judges - but not in non-partisan or non-competitive "retention" elections. This partisan voting behavior cannot be attributed to clear differences between Democratic and Republican judges in their sentencing decisions, since such differences, if any, are small and not consistent. Second, we find that incumbent judges' quality has little effect on their vote share or probability of winning in partisan general elections. By contrast, it has a substantial effect in non-partisan elections and partisan primary elections. It also has a noticeable effect on their vote share in retention elections, but the magnitude is often too small to affect reelection. Evidence on turnout is consistent with a simple "voting cue" hypothesis. We find that about $831 \%$ of the voters who vote on the top office on the ballot also vote on judicial elections in partisan elections. In contrast, in nonpartisan and retention elections, only 761\% and 67\\% of those who vote on the top office also vote on judicial candidates, respectively. In addition, the amount of newspaper coverage affects voter turnout only in non-partisan elections.
\end{abstract}

Claire S.H. Lim

Cornell University

clairelim@cornell.edu

James M. Snyder, Jr.

Harvard University

1737 Cambridge Street, CGIS

Knafel Building Room 413

Cambridge, MA 02138

and NBER

jsnyder@gov.harvard.edu 


\section{Introduction}

How can citizens select good government officials and hold them accountable for their behavior? This has long been an important question in economics (e.g., Barro (1973) and Ferejohn (1986)). Recently, there has been a growing interest in how the optimality of selection and retention systems for public officials depends on the nature of the tasks they perform (e.g. Alesina and Tabellini (2007)). This paper studies electoral systems used for public officials who perform bureaucratic tasks: U.S. state court judges. ${ }^{1}$

Most countries use the appointment system for public officials who perform bureaucratic tasks, such as trial court judges, prosecutors, regulators, school district superintendents, and city councillors. In contrast, a large number of U.S. states employ direct elections of such public officials. Many important issues surrounding this variation are not clearly understood. How voters behave in such elections? Under what circumstances is the direct election of these public officials desirable? On one hand, direct election of public officials may lead to selection of those whose preferences are well-aligned with voters. ${ }^{2}$ On the other hand, voters may largely be uninformed, as argued by Downs (1957), and voter behavior may be influenced by idiosyncratic and irrelevant factors, as argued by Bartels (2008). Additionally, the paucity of voter information in elections may lead to poor quality of elected public officials, or poor performance due to insufficient monitoring.

This paper empirically analyzes the institutional design of electoral processes, with a focus on voters' partisan voting behavior and the influence of candidate quality on voting outcomes. We highlight two comparisons: (1) partisan elections vs. non-partisan elections, and (2) competitive elections vs. non-competitive "retention" elections. We ask how much these features affect the degree to which voters base their votes on candidates' party affiliation, and whether these appear to increase or decrease the degree to which higher quality or better performing candidates receive more votes, and win more elections.

Why should these features of the electoral systems matter? On one hand, given the relatively strong party attachments of most U.S. voters, when voters know that candidates' party affiliations are listed on the ballot they might not search for other information that is more difficult to find and remember. ${ }^{3}$ Information about candidate quality or performance is likely to fall into the "relatively difficult to find and remember" category. Moreover, party polarization in the U.S. has been relatively high for at least the past two decades, and a variety of different models predict that when polarization is high, candidate quality and performance will have less impact on voting outcomes. ${ }^{4}$ In addition, many voters choose to abstain in non-partisan elections. It is possible that

\footnotetext{
${ }^{1}$ Although state supreme court judges have some "policy-making" function, they constitute only about $3.5 \%$ of our election data. Most judges in our data are state trial court judges, in charge of routine tasks such as keeping an order in court trials rather than ideological policy making.

${ }^{2}$ Besley and Coate (2003) show that selecting regulators through direct election as opposed to appointment yields the types of regulators who will conform to voters' preference rather than the organized interests of the electric power industry.

${ }^{3}$ Stumpf and Culver (1992) make this argument: "In partisan [judicial] races, the political party label may give most voters all the information they seek."

${ }^{4}$ See, for example, Ashworth and Bueno de Mesquita (2008), Padro i Miquel (2007), and Besley et al. (2005).
} 
those who vote in non-partisan elections have more information of the "relatively difficult to find and remember" variety than those who do not. On the other hand, partisan competition may also have an opposite effect. When there is strong inter-party competition, political parties may have strong incentives to recruit, support, and disseminate information about high-quality candidates, leading to a better quality of elected public officials. ${ }^{5}$

The state judiciary is an ideal context to study these issues for several reasons. First, there is unique variation in the rules by which state court judges are selected and retained. Specifically, three systems are dominantly used: in partisan elections, candidates compete with party affiliation; in nonpartisan elections, candidates compete without party affiliation; and in retention elections, there are no challengers, and voters cast a yes-or-no vote on incumbents. (See Table 1 and Section 2.1 for details.) Second, in many states, one or more bar associations routinely evaluate the "quality" of judges and judicial candidates and publish these evaluations. In a few states, a state commission compiles and publishes evaluations. Newspapers often print stories about these evaluations as well. We use two newly collected data sets, one on election results and one on judicial evaluations. The election data covers state court judges in 39 U.S. states over the period 1990-2010. The judicial evaluation data covers 24 states, and its time frame varies considerably across states and localities. Third, the nature of judges' tasks and the scope of their discretion are fairly uniform across states, which makes cross-state comparison of their selection systems and their behavior viable.

Our findings are summarized as follows. First, we find that voting is highly partisan in partisan judicial elections - i.e., there is a strong correlation between the Democratic "normal vote" and the Democratic vote share for judges - but not in non-partisan or retention elections. ${ }^{6}$ This partisan voting behavior cannot be attributed to clear differences between Democratic and Republican judges in their sentencing decisions, since such differences, if any, are small and not consistent.

Second, we find that the quality of judicial candidates has relatively little effect on their vote share or probability of winning in partisan general elections. By contrast, the quality of judicial candidates has a substantial effect on their vote share and probability of winning in non-partisan elections and in partisan primary elections. ${ }^{7}$ Incumbent judges' quality also has a noticeable effect on their vote share in retention elections, although the magnitude is rarely large enough to affect reelection. It is possible that the presence of opposing candidates and a relatively high degree of

Banerjee and Pande (2007) yields similar kinds of predictions in a multi-party environment.

${ }^{5}$ Besley et al. (2010) show that strong inter-party competition leads to pro-growth economic policies such as lower tax rates, higher capital spending, and increased use of right-to-work laws.

${ }^{6}$ We are not the first to document this. See Dubois (1980) for an early analysis, and Squire and Smith (1988) and Klein and Baum (2001) for experimental evidence. All of these studies, like almost all existing work, focus exclusively on high court judges.

${ }^{7}$ We are only aware of two previous studies that attempt to estimate the impact of bar association evaluations on voting. Goldstein (1979-1980) studies the 1977 judicial elections in Louisville, Kentucky. Dubois (1984) studies superior court elections in California over the period 1976-1980. Goldstein finds that bar association evaluations have a large impact on voting. Dubois finds a smaller effect, although it is still positive and statistically significant. Moreover, Dubois includes controls for incumbency, campaign spending, and newspaper endorsements in his regressions; since these are correlated with quality, his estimates probably understate the overall "reduced form" effect of quality, which is the quantity of interest to us. California and Kentucky use non-partisan elections, so these findings are generally consistent with ours. 
competition are necessary in order for information about candidate quality to reach a large share of the electorate. ${ }^{8}$

Note that candidate quality matters to some degree even in partisan electoral systems, because the primary elections help to eliminate the low-quality candidates. ${ }^{9}$ However, partisan general elections do not do much to eliminate weak candidates, except in areas where the distribution of voters across parties is relatively balanced. Therefore, when one party is favored in an area, competition in the favored party's primary is the key to preventing low-quality candidates from winning office. In addition, we do not find that partisan elections are significantly more competitive than non-partisan elections in terms of the number of candidates and victory margins.

Finally, the evidence on turnout is consistent with a simple "voting cue" hypothesis. We find that about $83 \%$ of the voters who vote on the top office on the ballot also vote on judicial elections in partisan elections. In contrast, in nonpartisan and retention elections, only $76 \%$ and $67 \%$ of those who vote on the top office also vote on judicial candidates, respectively. In addition, the amount of media coverage affects voter turnout only in non-partisan elections.

These results have an important implication. The desirability of electing local public officials through partisan competition critically depends on the nature of the officials' tasks, the ideological variability of decisions by public officials from different parties, and the heterogeneity of voter preferences. If the primary task of public officials is not to represent voters' ideology and their decisions do not vary much across parties, then the adverse effect of partisan competition on candidate quality may outweigh the benefit of reflecting voters' party preferences in election outcomes. To the extent that partisan voting behavior crowds out the influence of candidate quality on voting outcomes, the desirability of partisan election systems may need to be re-considered.

This paper contributes to a literature on judicial selection mechanisms, in addition to the aforementioned literature on electoral competition and candidate quality. There have been several studies that focus on elections of state supreme court judges. For example, Hall (2001) documents statistics of judicial elections for state supreme court judges, such as the overall rate of incumbent judges being challenged and defeated, and the average vote share. In a recent book, Bonneau and Hall (2009) document important patterns in state supreme court elections such as rate of challenges against the incumbent and campaign spending. This paper substantially expands the scope of our understanding of the selection systems by conducting a large-scale analysis of state trial courts and state lower appellate courts, as well as an analysis of the role of candidate quality based on newly collected ratings data. ${ }^{10}$

\footnotetext{
${ }^{8}$ Dubois (1980) makes this argument: "when judicial elections are highly competitive and controversial, voters demonstrate a remarkable ability to learn about candidates, to correctly match them with their positions [on issues], and to vote accordingly."

${ }^{9}$ Of course, "smoke-filled rooms" or party conventions might also eliminate these candidates. For example, the judicial nominating conventions used in New York do not appear to yield a larger percentage of "unqualified" candidates than the primaries in similar states such as Illinois and Pennsylvania.

${ }^{10}$ In a review of Bonneau and Hall (2009), Wasby (2009, p. 293) writes: "This makes limiting [Bonneau and Hall's] study to state high courts the book's greatest substantive defect, which is not adequately excused on the basis that 'obtaining systematic data on lower court elections over any substantial period is a nearly impossible task' (p. 18)... Presenting data limited to state high courts not only gives an incomplete picture, but also leaves the authors'
} 
Several studies in this stream of research also document the empirical relationship between the selection mechanisms and court decisions. For example, Gordon and Huber (2007) compare criminal sentencing decisions by appointed and elected judges in Kansas. They argue that the probability of incarceration is higher and the average sentenced jail time is longer when elected judges determine the outcome. Lim (2012) also analyzes sentencing decisions in Kansas, and finds that the sentencing harshness of elected judges is strongly related to the political ideology of the voters in their districts while that of appointed judges is not. She uses a structural model to estimate their preferences and reelection incentives and conducts counterfactual experiments of how the level of compensation for judges affect their reelection incentives and the relative advantages of each selection system. Lim, Snyder, and Strömberg (2012) study how media influences sentencing decisions by U.S. state trial court judges. They show that media influence is considerably larger for nonpartisan elected judges than for partisan elected or appointed judges, which is analogous to our result that candidate quality has the largest effect in nonpartisan elections. There also exist studies on the relationship between judicial selection systems and the death penalty (e.g., Gelman et al. (2004), Blume and Eisenberg (1999)) and civil case adjudication (Tabarrok and Helland (1999)). Our analysis of voting behavior under different electoral processes helps us to understand the mechanisms through which selection systems might affect the behavior of judges.

\section{Data}

\subsection{Data on Judicial Elections}

Table 1 summarizes the various systems for selecting and retaining trial court judges. There are three main systems in which voters play a direct role. First, in 9 states, judges are selected and retained through partisan elections. That is, judicial candidates seek party nomination through primary elections, then candidates from each party compete against each other in the general election, and party affiliations are listed on the general election ballot. ${ }^{11}$ Second, in 22 states, judges are selected through non-partisan elections. These are two-round systems. First, all judicial candidates run for elections without party labels on the ballot. Then, if no candidate wins a majority of the votes in the first round, the top two candidates compete in a runoff race. In almost all states, the first round elections are held at the time the state holds its primary elections, and the runoff elections are held at the time of the general election in the state. ${ }^{12}$ Third, in 10 states

paeans for elections to stand on only one use of a selection method. This is the same problem that results from over-attention to the U.S. Supreme Court - making generalizations based on far less than all appellate courts, much less trial courts."

Baum (2003, p. 18) also calls for more data on lower state courts: "the electoral fates of lower-court judges are spotty and largely out of date... All of these trial court studies were carried out prior to the past two decades, before strong campaigns against judicial incumbents became more common. But that growth has occurred primarily at the supreme court level, so it is likely that trial (and intermediate appellate) judges continue to do very well at the polls. Research to test the accuracy of this surmise would be useful."

${ }^{11}$ In New York candidates are nominated by party conventions rather than primaries.

${ }^{12}$ In most of states that have non-partisan elections, there is no nomination of candidates from political parties. In Ohio, candidates are nominated in partisan primaries, but the party labels do not appear on the ballot in the general 
judges are first appointed by the governor and then must face the voters at the end of each term in retention elections. These are elections with no opponents. Instead, voters choose whether or not to retain the judge ("yes" or "no"), and the judge continues in office if he or she receives a majority of "yes" votes. ${ }^{13}$

Tables 2 and 3 show summary statistics on the electoral data we have collected. The data contains results for judicial elections in 39 states, for all three levels of state courts - supreme courts, appellate courts, and trial (district) courts. ${ }^{14,15}$ Table 2 shows the number of candidaterace observations and the data period for each state. The data period varies somewhat across states, but it covers the past two decades (1990-2010) for a majority of the states.

Columns (1) and (2) of Table 3 present summary statistics on competition in partisan primaries and partisan general elections, respectively. They show two important features. First, partisan judicial elections exhibit a moderate, but non-negligible degree of competition in terms of the frequency of challenges. Among 8956 primary races, 2327 races (26.0\%) are contested. Similarly, among 6020 general election races, 1889 races (31.4\%) are contested. However, the winners' vote share shows that challenges may not result in close elections frequently. On average, the vote share of winners in contested general elections is $56.7 \%$.

Columns (3) and (4) of Table 3 present summary statistics on competition in non-partisan firstround and second-round elections, respectively. Perhaps surprisingly, these elections exhibit levels of competition similar to those of partisan elections, in terms of the frequency of challenges and the overall distribution of winners' vote shares. Partisan elections are only slightly more competitive. The lack of a substantial difference between the partisan and non-partisan elections suggests the influence of party on election outcomes, if any, is more likely to take place through channels other than affecting the degree of competition.

Table 4 presents summary statistics on retention elections. Evidently, judges running in retention elections are much safer than those who face competitive elections, either partisan or nonpartisan. The mean share of "yes" votes across states is $73.9 \%$, and the standard deviation is 6.7 percentage points. Even the 10th percentile of the share of "yes" votes is around or above $65 \%$ in most of states, showing that almost all incumbents are extremely safe in retention elections. In our sample, only 39 judges lost their retention election.

election. Michigan also has a similar process for the election of state supreme court judges.

${ }^{13}$ In Illinois a judge must receive a "yes" vote of $60 \%$ to be retained, and in New Mexico (after 1994) a judge must receive a "yes" vote of $57 \%$.

${ }^{14}$ When a state has multiple trial courts, we include only "general jurisdiction" trial courts - these are the courts that handle general civil and felony crime cases. We exclude "limited jurisdiction" courts that are restricted to handling minor civil cases, misdemeanors, and traffic cases.

${ }^{15}$ The source varies by state. For the most recent years we collected it directly from state websites - the Secretary of State or chief state election official, or state elections board. For earlier years we received copies of official election results from the relevant state officials. 


\subsection{Data on Judicial Evaluations}

Table 5 presents summary information on the judicial evaluations we have collected. In 6 states - Alaska, Arizona, Colorado, Kansas, New Mexico, and Utah - these evaluations are conducted by state commissions. ${ }^{16}$ The evaluations for other states are conducted by state or local bar associations, or by groups of bar associations. Local bar associations typically only evaluate the local trial court candidates. In all cases these evaluations are based on comprehensive surveys of attorneys. In some cases they also incorporate surveys of other judges, court employees, and citizens who have served as jurors or witnesses. For consistency we focus on the attorney surveys.

The surveys ask for the respondents' views on a variety of performance criteria, including integrity, judicial temperament, knowledge of the law, communication skills, diligence, professional competence, and case management. As an example, the following list shows items from the Colorado Commission on Judicial Performance survey:

1. Case Management:

1a. Promptly issuing a decision on the case after trial.

1b. Maintaining appropriate control over proceedings.

1c. Promptly ruling on pre-trial motions.

1d. Setting reasonable schedules for cases.

2. Application and Knowledge of Law:

2a. Being able to identify and analyze relevant facts.

2b. Basing decisions on evidence and arguments.

2c. Willing to reconsider error in fact or law.

2 d. Issuing consistent sentences when the circumstances are similar.

3. Communications:

3a. Making sure all participants understand the proceedings.

3b. Providing written communications that are clear, thorough and well reasoned.

4. Demeanor:

4a. Giving proceedings a sense of dignity.

4b. Treating parties with respect.

4c. Conducting his/her courtroom in a neutral manner.

4d. Consistently applying laws and rules.

5. Diligence:

5a. Using good judgment in application of relevant law and rules.

5b. Doing the necessary homework and being prepared for his/her cases.

5c. Being willing to handle cases on the docket even when they are complicated and time consuming.

\footnotetext{
${ }^{16} \mathrm{~A}$ number of states have recently established similar commissions or pilot programs. See http://www.ncsc.org/ topics/judicial-officers/judicial-performance-evaluation/state-links.aspx for details.
} 
Although the surveys address the same general performance criteria, the details - the number of items, question wording, response categories, and so on - vary widely across states and bar associations. There is also considerable variation in how the surveys and other information are aggregated into summary evaluations. In most cases, there is a bottom-line evaluation such as Well Qualified, Qualified, or Unqualified; Highly Recommended, Recommended, or Not Recommended; or (for retention elections) Retain or Do Not Retain. Other categories exist, including Outstanding, Strongly Recommended, Strongly Not Recommended, Adequate, Not Rated, and No Opinion. As a result, comparing across states requires considerable care.

To simplify our analysis we collapse the various categories into a dichotomous variable, which we call Score. We set $S$ core $=1$ for all candidates with evaluations of Qualified or better, Recommended or better, or Retain, and $S c o r e=0$ for candidates with evaluations of Not Qualified or worse, Not Recommended or worse, or Do Not Retain. ${ }^{17}$

State commissions and bar associations claim that one of the main reasons they evaluate judges and judicial candidates is to inform voters. The surveys are conducted during the months preceding elections and the evaluations are released within a few weeks of election day. The evaluations also tend to receive a non-trivial amount of newspaper coverage when they are released. As usual, bad news is good news when it comes to generating eye-catching headlines: "Lawyers Rank 9 Judges 'Unqualified"," "Lawyers Rate PA Judge Unfit," "Bar Association Rates Two Judicial Candidates as Unqualified," and "Democrat Gets Negative Rating from Bar in County Court Race" are examples. Sometimes, however, good news prevails: "Bar Group Rates Court Candidates -6 in Appellate Race Given Top Marks." 18

Although the survey items are not explicitly ideological or partisan, it is possible that the responses and resulting evaluations exhibit an ideological or partisan bias. Many conservative commentators argue that lawyers in general and bar associations in particular are liberal relative to the overall population. Thus, we might worry that evaluations are correlated with judges' ideologies or party affiliations. Even if they are not, voters might believe they are, and use them accordingly.

We check whether the evaluations from bar associations and state commissions appear to signal the ideological positions of candidates rather than quality, but find no consistent evidence for this. First, the correlation between evaluations and party affiliation of judges is small (see appendix Table A.6). Second, the correlation between judicial evaluations and the normal vote across precincts is

\footnotetext{
${ }^{17}$ Several Bar Associations do not provide a categorical bottom-line evaluation. Instead, for each candidate they report the fraction of respondents who gave various ratings. For the Houston Bar, we set Score=1 if more than $50 \%$ of the respondents gave a candidate a rating of Qualified or better, and Score $=0$ otherwise. For the Iowa State Bar, Missouri State Bar, and Nebraska State Bar, we set Score=1 if more than $60 \%$ of the respondents recommended retention, and Score $=0$ otherwise; for the Wyoming State Bar we set the threshold at $65 \%$. For the Utah State Commission, we set Score=1 if more than $75 \%$ of the respondents gave a recommendation of Adequate or better, and Score $=0$ otherwise. In Minnesota and Oregon the evaluations are in the form of preference polls, giving the percentage of respondents favoring each candidate. In these cases we set $S c o r e=1$ if a candidate received at least $25 \%$ support, and $S$ core $=0$ otherwise. We chose the thresholds so the percentage of "bad" candidates was approximately constant across the states with the same electoral system.

${ }^{18}$ In order, these headlines are from: Chicago Tribune, October 12, 1988; Philadelphia Inquirer, May 14, 2010; Ventura County Star; October 19, 1993; Syracuse Post-Standard, October 0, 2009; Chicago Tribune, March 2, 1990.
} 
also small - i.e., it is not the case that judges with higher evaluations receive a larger share of votes in Democratic precincts than in Republican precincts.

\section{Findings}

\subsection{Partisan Voting in Partisan, Non-Partisan, and Retention Elections}

We begin with an analysis of precinct-level data for a few states. For each precinct and year, we construct a "normal vote" measure by averaging the Democratic percentage of the two-party vote across all of the available federal and state partisan elections - president, U.S. senator, U.S. house, governor, state senator, state house representative, and various down-ballot offices such as state attorney general, secretary of state, and state treasurer. We call this the Democratic Normal Vote. We then collect the percentage of the two-party vote won by the Democratic candidate in each of the available contested judicial elections, and call this Democratic Vote for Judge. For each judicial election, we then correlate the Democratic Vote for Judge against the Democratic Normal Vote.

Table 6 shows the results. The patterns are clear: Voting is highly partisan in partisan elections, and much less partisan in non-partisan elections and retention elections. For example, in Texas the average correlation between Democratic Vote for Judge and Democratic Normal Vote is 0.99, and in Pennsylvania the average correlation is 0.91 . In North Carolina partisan elections the correlation is 0.93. In North Carolina non-partisan elections, on the other hand, the correlation is only 0.28. In non-partisan elections in Arkansas, California, Idaho, and Washington state the correlations are also small, and these probably overstate the true relationship because we assign partisanship to the judicial candidates to maximize the correlation. In Arizona and Colorado retention elections the correlations are also low.

In Illinois partisan elections the correlation is 0.91, while for Democratic incumbents in retention elections the correlation is just 0.37 , and for Republicans incumbents in retention the correlation is 0.28. Note that the correlation is positive for Republican incumbents - i.e., Republican incumbents receive a larger percentage of "yes" votes in Democratic precincts than they do in Republican precincts - which is the opposite of what we expect under partisan voting. Recall that these are the same candidates running first in partisan elections and then later in retention elections. ${ }^{19}$

Note that in Ohio, which has partisan primaries but no party labels on the general election ballot, the correlation in trial court races is 0.89 . This feature indicates that nomination by parties, as well as information on party affiliation on the ballot, affects voting behavior significantly.

We have county-level data for many other states. Although these analyses are cruder, they show the same basic patterns. In particular, the correlation between Democratic Vote for Judge and Democratic Normal Vote is much higher in partisan elections than in non-partisan or retention elections. In retention elections the correlations are also low.

\footnotetext{
${ }^{19}$ Using county-level data for the whole state, the correlation between Democratic Vote for Judge and Democratic Normal Vote is 0.71 in the partisan elections. For retention elections, the correlations are much smaller in absolute terms: 0.08 for Democratic judges and -0.29 for Republican judges.
} 


\subsection{The Case of Retention Elections in Cook County, IL}

One of the pronounced patterns we documented above is the lack of partisan voting in retention elections. In this subsection, we document a further analysis of voting patterns in retention elections, using a unique subgroup of retention elections in which judges are likely to face voters with the political ideology opposite to the judges' party: retention elections in sub-circuits of Cook County, Illinois. Circuit court judges in Cook County are all initially elected through partisan elections. However, there is variation in the scope of voters that candidates face. The Cook County judicial circuit is divided to 15 sub-circuits. Among 262 judges, 107 judges are initially elected by constituents in the entire Cook County, i.e., they are "at-large" judges. The other 155 judges are initially elected by voters in a sub-circuit. When judges are up for reelection, they face retention elections by voters in the entire Cook County, regardless of how they were initially elected. Therefore, judges initially elected in a sub-circuit face retention elections by voters that are different from voters who initially elected them.

Analyzing these retention elections of Cook County judges is useful to alleviate the following sample selection problem in the comparison of voting behavior in non-retention (partisan and non-partisan) elections and retention elections. In measuring the degree of partisan voting in partisan and non-partisan elections, we use only contested elections that have both Democratic and Republican candidates. A contested election takes place when there is an open seat or the incumbent is not strong enough to deter challengers. Moreover, two-party races are likely to happen when the voter ideology is not too lop-sided. That is, the ideology of the constituency is balanced enough to encourage both Democratic and Republican candidates to enter the race. By contrast, for retention elections, we measure the partisanship in voting behavior using all the elections. Moreover, candidates are all incumbents, which implies that they are already popular enough in their jurisdiction to be selected in the first place. Thus, incumbents that would be strong enough to run unopposed and hence excluded from measurement for partisan elections are all included in the measurement for retention elections. As a result, compared with partisan elections, retention elections are more likely to include candidates who get a strong support from voters regardless of their party affiliation, which may be confounded with the effect of electoral processes. The subcircuit structure in Cook County forces incumbents to face voters in reelection that may not find them as appealing as voters in their sub-circuit do.

The left panel of Figure 1 shows the composition of Cook County judicial sub-circuits outside the City of Chicago. The right panel shows the ward-level political ideology of voters, measured by the vote shares of Democratic and Republican candidates in the 2008 presidential election. Among fifteen judicial sub-circuits in Cook County, three sub-circuits are located entirely within the City of Chicago (sub-circuits 5, 6, and 8) and four sub-circuits are located entirely outside the City of Chicago $(4,12,13$, and 15). The other eight sub-circuits have territory in both the City of Chicago and the outer counties $(1,2,3,7,9,10,11$, and 14). Overall, Cook County is dominantly Democratic, except for the four sub-circuits located entirely outside Chicago. We document retention elections of 123 circuit (trial) court judges in Cook County for whom we 
have precinct-level voting data. Among these judges, seventeen are Republican and the rest are Democrat. Among seventeen Republicans, sixteen are were initially elected in partisan elections in one of the four sub-circuits $(4,12,13$, and 15) favorable to Republican, and one was elected at-large in a partisan election in the entire Cook County.

Table 7 shows the summary statistics of the estimates of partisan voting (the correlation between judges' share of yes-votes and the Democratic Normal Vote) and the share of yes-votes using precinct level data. The statistics clearly show two features. First, the degree of partisan voting behavior is relatively small. Second, judges receive a large share of affirmative votes regardless of whether they face voters that are favorable to their party or not. These patterns strengthen our conclusion that the degree of partisan voting is very weak in retention elections.

\subsection{Candidate Quality and Voting in Partisan, Non-Partisan, and Retention Elections}

Tables 8 and 9 present results on the relationship between judicial evaluations and election results in the various types of elections.

Table 8 shows aggregate summary statistics on win percentages. Each observation is a candidate, and all elections are included. The cell entries are means, with the associated number of observations in parentheses. The table shows that for all types of elections, candidates with $S$ core $=1$ are much more likely to win than candidates with $S c o r e=0$. Overall, candidates who are judged to be Unqualified, Not Recommended, etc. rarely win office. In fact, such candidates constitute only about $6 \%$ of the final winners for all of the candidates for which we have evaluations.

This appears to be moderately good news for democracy - at a minimum, the electoral process seems to be weeding out most of the least qualified candidates. However, there are a variety of possible reasons for this. One possibility, of course, is that voters learn the candidates' relative evaluations and vote accordingly. But it would not be surprising if other factors played an even more important role, including strategic entry (low-quality candidates are opposed more often), incumbency advantage (incumbents tend to receive higher evaluations but they might also enjoy other electoral advantages as incumbents), campaigning and media coverage (high-quality candidates might raise more money and receive favorable coverage as well as endorsements), and so on.

Table 9 carries the analysis further. In this table we restrict attention to contested races in which the top two candidates received more than $90 \%$ of the vote. ${ }^{20}$ We then make one observation for each race. For partisan general elections the results are presented from the point of view of the Democratic candidate. For primary elections and non-partisan elections the results are presented from the point of view of the candidate whose name is first in alphabetic order. We call this candidate the "Alpha candidate." The cell entries give the estimated coefficient on the variable "Relative Score" from simple OLS regressions with either "Win Percentage" or "Vote Percentage" as the dependent variable. Relative Score is equal to the score of the Democratic or Alpha candidate minus

\footnotetext{
${ }^{20}$ Also, in the case of partisan general elections, there must be one candidate from each of the major parties.
} 
the score of his or her opponent (and thus can be $+1,0$ or -1 ). Vote Percentage is the percentage of votes won by the Democratic or Alpha candidate, and Win Percentage is a dummy variable equal to 100 if the Democratic or Alpha candidate wins and 0 otherwise. ${ }^{21}$ We include constituency fixed effects to focus only on the various choices available to voters within each constituence. In sum, we estimate the following equations:

$$
\begin{aligned}
\text { Win Percentage }_{i t} & =\beta_{0}+\beta_{1} \text { Relative Score }_{i t}+\beta_{2} x_{i t}+\epsilon_{i t} \\
\text { Vote Percentage }_{i t} & =\beta_{0}+\beta_{1} \text { Relative Score } \\
i t & +\beta_{2} x_{i t}+\epsilon_{i t}
\end{aligned}
$$

where $x_{i t}$ is a constituency fixed effect.

Several patterns are clear from the table. In the partisan general elections in Illinois and Texas (top panel), the Democratic candidate is more likely to win if he or she has a higher evaluation than the Republican candidate, and he or she also receives a larger share of the votes. However, the differences are not huge. The estimated coefficients for Win Percentage are just 4.5 and 1.7, and neither is statistically significant at the .05 level. The estimated coefficients for Vote Percentage are just 0.9 and 2.1 .

By comparison, the differences are much larger in the two-candidate primary elections in these states (second panel). In Illinois and Texas, the estimated coefficients for Win Percentage are 30.0 and 24.4, and both are highly significant. The estimated coefficients for Vote Percentage are 9.5 and 10.5 - about 5 times as large as those in the partisan case - and they are again highly significant. We observe similar patterns in Ohio partisan primaries.

The differences are similarly large in the non-partisan elections (primary or general) in California, Minnesota, Oregon, Washington, and Wisconsin. The estimated coefficients for Win Percentage range from 29.7 to 47.4, and the estimated coefficients for Vote Percentage range from 7.2 to 16.3. All are highly significant.

In Ohio we know each candidate's party since they run in partisan primaries, but party is not printed on the general election ballots. The general election results in Ohio are closer to those for the "pure" non-partisan cases than the partisan cases for the Win Percentage variable. For the Vote Percentage variable the results lie about halfway between the pure partisan and non-partisan estimates. $^{22}$

In terms of Vote Percentage, the estimated effects of Score are similarly large in retention elections. On average, incumbent judges in Illinois with $S$ core $=1$ receive a vote percentage that is 10.1 percentage points higher than incumbent judges with $S c o r e=0$, and are $19.7 \%$ more likely to win. Overall, there are large differences in Vote Percentage between judges with Score=1 and those with $S$ core=0. The results for Win Percentage are more mixed, varying widely from state to state due to the small number of incumbents who lose. On average, while very few judges receive

\footnotetext{
${ }^{21}$ We use 100 rather than 1 so that coefficients can be interpreted as percentage effects.

${ }^{22}$ The vast majority of primaries are uncontested, so we cannot conduct a separate analysis of contested primaries. This is also reflected in Table 8 , which shows that over $80 \%$ of primary candidates win, almost regardless of their evaluations.
} 
a Do Not Retain recommendation, those who do are more likely to lose than win.

The analysis above ignores incumbency. That is, the estimates in Table 9 combine the effects of Score with the effects of incumbency. However, although Score and incumbency are positively correlated, when we control for incumbency the large differences between the partisan and nonpartisan cases are essentially unchanged. This is in part due to the fact that the incumbency advantage in trial court elections, while positive, appears to be relatively small. ${ }^{23}$ The results for Illinois are indicative, since in these cases incumbency is held fixed - all retention elections involve incumbents, and all of the partisan primary and general elections are to fill vacancies.

Other cases exhibit similar patterns. New York has partisan general elections for judges, and nominations are made by party conventions. In New York City between 1999 and 2010, there were 160 Democratic candidates and 56 Republicans with New York City Bar Association (NYCBA) evaluations. ${ }^{24}$ Among the Democratic candidates, 150 were Approved by the NYCBA (Score=1), 9 were Not Approved (Score=0), and 1 was Not Evaluated (dropped). All of the Democrats won election. Most likely, this is because judicial elections in New York are partisan and voters in New York City overwhelmingly identify with the Democratic party. New York has multi-seat races, so we can run regressions with race-specific fixed effects and thus compare candidates with different evaluations running at the same time for the same offices. After controlling for party affiliation (and race-specific fixed effects), the NYCBA evaluations appear to have essentially no effect on voting. The estimated coefficient on Score is 0.81 with a standard error of 1.02 , implying that an Approved evaluation increases a candidate's expected vote share by less than 1 percentage point. Since the typical Democrat won with a margin of about 15.5 percentage points, it is unlikely that the evaluations affect who wins and who loses.

The situation is similar in Pennsylvania, which also has partisan general elections, as well as partisan primaries. We have evaluations for 136 Democratic candidates and 38 Republicans who ran in a general election (not for retention) in Philadelphia or Allegheny counties - about half from the Philadelphia Bar Association and half from the Allegheny County Bar Association. ${ }^{25}$ Among the Democratic candidates, 117 were Recommended and 19 were Not Recommended or Unqualified. All but one of the Democrats won election. Again, this outcome is likely due to the fact that Pennsylvania has partisan judicial elections, and Philadelphia and Pittsburgh are both heavily Democratic cities. Pennsylvania has multi-seat races, so we can run regressions with racespecific fixed effects and thus compare candidates with different evaluations running at the same time for the same offices. After controlling for party affiliation (and race-specific fixed effects), the bar evaluations appear to have essentially no effect on voting. The estimated coefficient on Score is -0.28 with a standard error of 0.50 , implying that a Recommended evaluation decreases a

\footnotetext{
${ }^{23}$ This is conditional on having two candidates in the race. A large proportion of incumbents are not opposed either in the primary or the general election.

${ }^{24}$ Because candidates in New York may be nominated by more than one party, 91 of the Democrats were also nominated by the Republican party.

${ }^{25}$ As in New York, candidates in Pennsylvania may be nominated by more than one party, so 86 of the Democrats were also nominated by the Republican party.
} 
candidate's expected vote share by less than one-have of one percentage point. ${ }^{26}$ Thus, it is again unlikely that the evaluations affect who wins.

Fortunately, most of the lower-quality candidates in Philadelphia and Allegheny counties are eliminated in the primary elections - or at least in the Democratic primary, which is what matters. There were 96 candidates with Score $=0$ running in Democratic primaries in our sample. Of these, only 17 , or $17.7 \%$, won a Democratic nomination and went on to the general election.

From the analysis documented above, we can draw two important conclusions. First, partisan voting behavior appears to "crowd out" the influence of candidate quality on election outcomes in partisan general elections. Second, non-partisan elections function fairly effectively in terms of reflecting candidate quality in election outcomes.

Before proceding, we must consider two issues regarding these conclusions. The first issue is whether partisan voting behavior in the partisan election system is due mainly to the electoral process itself, or whether it might be attributable at least in part to the underlying preferences of voters. In particular, it might be the case that electoral systems across states are tailored somewhat to voter preferences. Are voters more intensely partisan or more ideologically polarized in states with partisan judicial elections compared to voters in states with nonpartisan or retention election systems? The second issue concerns the mechanisms through which candidate quality is reflected in voting outcomes in partisan primaries and non-partisan elections. Given that most of the voters do not acquire much information about judicial candidates, the mechanism through which candidate quality affects voting outcomes may not be self-evident.

To address the first issue, we turn to survey data, in particular the American National Election Studies (ANES). We pool the ANES data from 1990 to 2004 and focus on three items: the 7-point scale of party identification, the 7-point scale of ideological self-placement, and the -100 to 100 "feeling thermometer" measuring the difference in how warm the respondent feels toward liberals compared to conservatives. We fold the party identification item around its mid-point of 4 , to make a variable measuring the strength of party attachments. This variable takes on the following values: $0=$ pure independent, $1=$ independent but lean toward Democratic or Republican party, $2=$ weak Democrat or weak Republican, and $3=$ strong Democrat or strong Republican. We also fold the ideological self-placement item around its mid-point of 4, to make a variable measuring ideological extremity. This variable takes on the values: $0=$ moderate (middle of the road), 1 $=$ slightly liberal or slightly conservative, $2=$ liberal or conservative, and $3=$ extremely liberal or extremely conservative. We fold the feeling thermometer item around its mid-point of 0 , so the resulting variable is 0 for respondents who like liberals and conservatives equally, and 100 for respondents who like one group intensely and dislike the other intensely.

The summary statistics for these three variables are shown in Table 10. The bottom line is simple: there are essentially no differences between voters living in states with partisan judicial elections and voters living in states with non-partisan elections or retention systems. In regressions,

\footnotetext{
${ }^{26}$ As in New York, the number of votes available per voter varies across races, depending on how many positions are filled. We therefore also analyzed "normalized" vote-shares. Again, the results are qualitatively similar to those for the raw vote-shares.
} 
none of the differences between the three types of states with judicial elections are statistically significant. ${ }^{27}$

Regarding the second issue, it is useful to note the following three points. First, our estimates do not imply that a large fraction of the electorate appears to take candidate quality into account in their voting. Rather, the percentage is probably only about $10-20 \%$ of those who vote in judicial elections. This is an even smaller fraction of the voting age population, since turnout in primary elections is typically only around 20-25\%, and in non-partisan general elections it is only around $25-40 \%$ (due to roll-off). It is plausible that $5 \%$ of U.S. adults follow elections closely enough that they are exposed to information about judicial candidate quality during an election. Second, political psychologists argue that voters store much of the information they see and hear during campaigns as impressions. Voters form impressions about candidates, and can remember and use these impressions, even though they are unable to remember the exact set of facts or events that led to these impressions. It is therefore difficult to know what facts or falsehoods - i.e., what combination of newspaper stories, campaign ads, conversations with friends, family and co-workers, etc. - shape voters' impressions. ${ }^{28}$ Third, in many cases a bad rating can lead to a more vigorous campaign by the opposition (either a candidate or an interest group), and this will dramatically increase the number of people who might hear something bad about the judge with the bad rating (and store an unfavorable impression).

\subsection{Partisanship and Sentencing}

We now ask whether there are any clear partisan differences in the sentencing decisions of Democratic and Republican judges. ${ }^{29}$ This would provide a clear rationale for the partisan patterns exhibited in the voting data. However, we find few systematic differences in sentencing that are correlated with partisanship.

We employ criminal sentencing decisions from the National Judicial Reporting Program (NJRP). This database only reports information about the county where each case was heard, not the individual judge hearing the case. However, for a large number of counties we can construct a measure of the overall partisan composition - the fraction of judges in the county who are Democrats - in each year. We can then investigate whether the sentences tend to be relatively harsher in counties with a smaller or larger fraction of Democratic judges.

Table 11 shows the results for Texas, and also for Alabama, Illinois, Indiana, Kansas, Louisiana, New Mexico, and Ohio pooled. These are the states for which we can measure the partisan com-

\footnotetext{
${ }^{27}$ For the Partisan Intensity variable, the difference between states with appointed judges and the other types is statistically significant. But the magnitude of the difference is small: about 0.16 on a scale from 0 to 3 with an overall standard deviation of 0.98 .

${ }^{28}$ See, for example, McGraw (2003). Psychologists would call this is a form of "gist" memory - the ability to remember the gist of a story without being able to remember almost any details.

${ }^{29}$ Typically, criminal and civil cases each constitute approximately half of the caseloads. (See court statistics by National Center for State Courts at http://www.ncsc.org/services-and-experts/areas-of-expertise/court-statistics.aspx.) However, only criminal sentencing is appropriate for the purpose of measuring trial court judges' "ideology". In criminal cases, judges have discretion on sentencing even when conviction is done by jury. In contrast, adjudication in civil cases is primarily conducted by jury.
} 
position of the district for a sufficiently large number of cases. We present the results separately for Texas, because it is a key case, and because it has a huge number of cases and a large number of court districts and counties. ${ }^{30}$ We use the NJRP data for the period of 1990-2006. The NJRP data contains detailed case-level information such as the nature and number of convictions, offense category, sentence length, and penal code citation. We analyze the relationship between the county-level share of Democratic judges and sentencing harshness for four different offense categories: violent crimes, property crimes, drug crimes, and other crimes. To minimize measurement error in sentencing harshness caused by the heterogeneity of cases, we compare criminal cases only with other cases in the same year and with the same penal code citation. In order to classify cases, we generate a penal code variable that takes the same value for all crimes in each year that has the same penal code citation for the 1st, 2nd, and 3rd most serious offenses. Then, for each category, we collect minimum and maximum sentence given for that penal code. The dependent variable we use, normalized harshness of sentencing is defined as follows:

$$
\text { Relative Harshness }=\frac{\text { Sentence }-\min }{\max -\min } .
$$

The independent variable of interest is Share of Democratic Judges. A positive coefficient on this variable implies that Democratic judges cast harsher sentences than Republican judges, and a negative coefficient implies the opposite. We present two sets of results, one that that includes all available observations, and one in which we restrict attention to "smaller" judicial districts, defined as districts with no more than 10 judges.

The result of the regressions show a mixed pattern. First, for Texas half of the point estimates are positive and half are negative. Even with many thousands of observations, only half of the estimated coefficients are statistically significant at the .05 level; of these, two are positive and two are negative. Also, for two offense categories - drug crimes and other crimes - the coefficients switch sign depending on the sample uses. The magnitudes are small as well. For example, the .037 point estimate for violent crimes implies that the average normalized sentence length is .037 higher in a district with all Democratic judges, compared to one with all Republican judges. In the other states the coefficients are uniformly negative, but again small in magnitude. Only one is statistically significant at the .05 level.

Violent crimes constitute most of the "high-profile" cases that draw the attention of the public, so this category is probably the most important from the point of view of voting. For these cases the data suggest that in Texas Democratic judges are, if anything, slightly tougher than Republican judges. In the other states the data suggest the reverse, but the coefficient estimates are statistically insignificant.

Overall, then, the results indicate that the partisan voting behavior documented above cannot be attributed to voters responding to large and systematic partisan differences in the actual pattern of sentencing decisions.

\footnotetext{
${ }^{30}$ Illinois is another key case. We do not present Illinois separately, because over $93 \%$ of the observations are in Cook county.
} 


\subsection{Turnout}

The partisan voting behavior documented in Section 3.1 indicates that the way voters use information about candidates differs substantially across electoral processes. To investigate this issue further, we now turn to an analysis of voter turnout. We first document the variation in voter turnout across election systems. We focus on the relative turnout, which is defined as follows:

$$
\text { Relative turnout }=\frac{\text { number of votes cast on judicial elections }}{\text { maximum number of votes cast on major elections on the same ballot }}
$$

in which the major elections on the same ballot are presidential, gubernatorial, U.S. House, and U.S. Senate elections. Using the relative turnout, rather than the absolute turnout (the number of voters who cast a vote as a proportion of eligible voters), helps us to focus on voters' usage of information about candidates and abstract from the calculation of the cost of voting in analyzing voters' choice to vote. A typical voter decides whether to go to the voting booth or not by comparing the cost of voting and the benefit from voting on their preferred candidates in major elections. ${ }^{31}$ Once a voter goes to the voting booth to vote in major elections, the additional cost of voting on other offices is negligible. Hence, the decision to vote in judicial elections is determined by how sufficient voters regard their information about candidates, and it is unlikely to be influenced by the cost of voting. ${ }^{32}$

Table 12 shows that the turnout rate is highest in partisan elections, followed by nonpartisan and retention elections. The difference in turnout rates between partisan and nonpartisan elections shows that information about party affiliation induces some voters who may not vote in the absence of such information to vote on judicial elections. In addition, the substantial difference between non-partisan and retention elections shows that competition is important for providing information about candidates to voters. These features lead us to the following question: Does the information about party affiliation on the ballot or the competitiveness of the electoral processes affect voters' sensitivity to alternative sources of information about candidates? We investigate this issue by estimating the influence of the amount of newspaper coverage about judges on the turnout rates.

A main concern in identifying the causal effect of newspaper coverage on turnout rates is that both may be driven by unobserved factors. For example, if a judge makes a controversial decision in a high-profile case, it would increase both media coverage and voter turnout in judicial elections. To address this issue, we use a measure, Congruence, based on the degree of match between judicial districts and the circulation of newspapers, to capture the intensity of newspaper coverage of the courts. ${ }^{33}$ Our basic premise is that newspapers cover more stories about districts in which they have a large share of readers. Therefore, in the places where congruence between judicial districts

\footnotetext{
${ }^{31}$ The benefit from voting can be non-negligible if voters take into account the welfare of a large group of citizens who share their political preference, as in the model by Coate and Conlin (2004).

${ }^{32}$ In the literature on voter turnout, scholars often argue that voters abstain from down-ballot elections such as state court elections primarily because they do not have enough information about candidates (e.g., Feddersen and Pesendorfer (1996)).

${ }^{33}$ See Lim, Snyder, and Ströomberg (2012) for details of this approach, and Snyder and Strömberg (2010) for the application of this approach to the analysis of media influence on congressmen.
} 
and newspaper markets is high, newspapers have strong incentives to cover stories about courts. More precisely, to construct the definition of Congruence, we consider a simple positive relationship between the number of articles, $q_{m d}$, that a newspaper $m$ writes about a judge in judicial district $d$ and the share of newspapers' readers that live in judicial district $d$, ReaderShare Rd $_{\text {, that is, }}$

$$
q_{m d}=\alpha_{0}+\alpha_{1} \times \text { ReaderShare } e_{m d}, \text { where } \alpha_{1}>0 \text {. }
$$

Typically, multiple newspapers circulate in a judicial district. Hence, we aggregate over multiple newspapers sold in a judicial district. Congruence of judicial district $d$ is the average ReaderShare md weighted by the market share of each newspaper:

$$
\text { Congruence }_{d}=\sum_{m=1}^{M} \text { MarketShare }_{m d} \times \text { ReaderShare } \text { Rd }_{m}
$$

where MarketShare Md $_{d}$ is newspaper $m$ 's market share in judicial district $d$. Figure 2 illustrates cases of high and low congruence. The left panel shows an example of perfect congruence between judicial districts and circulation areas of newspapers (Congruence=1). In such a situation, events taking place in a judicial district are relevant to all the readers of the newspaper sold in that judicial district. Hence, newspapers have strong incentives to cover many stories about courts in that judicial district. In contrast, the right panel shows an example of low congruence (Congruence $=1 / 2)$. In such a situation, events that take place in a judicial district are relevant only to half of the readers of the newspapers sold in that judicial district. Hence, newspapers have a weaker incentive to cover stories about courts.

Our data on the newspaper coverage of state trial court judges, which is from Lim, Snyder and Strömberg (2012), contains the coverage of 9,828 state trial court judges for 2004-2005 by 1,400 newspapers in NewsLibrary.com. There are on average 60 newspaper articles per year, newspaper, and judicial district. The congruence measure has mean .22 and standard deviation .31. An increase in Congruence from 0 to 1 is associated with an increase in the number of articles per judge by 24 articles.

To measure the influence of newspaper coverage on turnout, we estimate the following equation:

$$
\begin{aligned}
\text { Turnout }_{i t}= & \beta_{0}+\beta_{1} \text { Congruence }_{i t}+\beta_{2} \text { Congruence }_{i t} * \text { Nonpartisan }_{i t} \\
& +\beta_{3} \text { Congruence }_{i t} \times \text { Retention }_{i t}+\beta_{4} \text { Nonpartisan }_{i t}+\beta_{5} \text { Retention }_{i t}+\beta_{6} x_{i t}+\epsilon_{i t}
\end{aligned}
$$

in which Nonpartisan is an indicator variable of nonpartisan elections, Retention is an indicator variable of retention elections, $x_{i t}$ is a set of demographic variables, and $\epsilon_{i t}$ is random disturbance. Table 13 shows the results of this regression. The result shows that there is no effect of newspaper coverage in partisan and retention elections. By contrast, in non-partisan elections, there is a statistically significant positive effect. Column (3) shows that courts with the highest congruence (Congruence $=1$ ) have 7.9 percentage points higher relative turnout rates than those with the lowest 
congruence (Congruence $=0$ ).

This result is consistent with the implication of the partisan voting behavior documented in Section 3.1. In partisan elections, since voters base their votes mostly on party affiliation, other information conveyed through media would not influence the decision to vote. By contrast, in non-partisan elections, the shortage of voter information about judicial candidates let voters rely on other sources of information, which leads to positive marginal effect of newspaper coverage on turnout. Lastly, in retention elections, the alternative to incumbents is not determined at the point of election, because there are no challengers. Therefore, the benefit from acquiring information about judicial candidates is negligible from voters' point of view. Moreover, the information about judicial candidates generated by media coverage may not be disseminated effectively, due to the absence of challengers, which further reduces the influence of newspaper coverage.

\section{Discussion}

Do partisan electoral systems tend to produce judges of lower quality than non-partisan or retention election systems? The results above identify one force pushing in that direction: the relatively weak relationship between quality/performance and voting decisions in partisan general elections. There are, however, countervailing forces. First, the results above also show that in the primary elections in partisan systems voters appear to use quality/performance relatively heavily in their voting decisions. So, the comparison between non-partisan and partisan systems might really boil down to a comparison between one system in which there are two good opportunities for quality/performance to make a difference in the electoral outcome (non-partisan), and another system in which there is only one. If one opportunity is all it takes, then the systems might yield similar outcomes.

Other factors might also play a role. For example, party elites might have a stronger incentive to attempt to screen out low quality judges in partisan systems, in order to maintain a good reputation or "brand name" for the party. Party leaders can endorse higher quality candidates in the primaries, or provide campaign funds or other resources to the higher quality candidates, to help them defeat those of lower quality. Of course, the ability of party leaders to affect primary election outcomes depends on the strength of their organizations and the amount of resources they control. Conventional wisdom holds that party organizations are weak in most states and localities, and party leaders control few resources.

Two pieces of evidence suggests that the systems do, in fact, produce difference outcomes. And, consistent with our results above, the evidence suggests that quality/performance is worse in partisan systems.

The first piece of evidence comes from evaluations of court systems by the U.S. Chamber Institute for Legal Reform, a division of the U.S. Chamber of Commerce. These studies, entitled State Liability Systems Ranking Study, which have been released annually since 2002, are based on surveys of "a nationally representative sample of in-house general counsel, senior litigators and 
other senior attorneys who are knowledgeable about litigation matters at companies with annual revenues of at least $\$ 100$ million." This is the most relevant item for our purposes that asks respondents to rate "Judges' Competence."

Table 14 shows the averaging rank of the states within each judicial selection system, for each year. In each year, the best state has a rank of 1 and the worst has a rank of $50 .{ }^{34}$ We show the years separately, because, although the year-to-year correlations are high (the average correlation is .86) there is also a non-trivial amount of movement. The bottom line is clear: in every year, states with partisan elections are ranked significantly lower than other states. Interestingly, there is also a clear difference between states with non-partisan elections and states with the appointment system. ${ }^{35}$

The second piece of evidence comes from a study of judicial malfeasance over the period 19852007, by Goldschmidt, Olson and Ekman (2009). The data there suggests that malfeasance tends to take more severe forms in partisan systems than other systems. More specifically, when we take the figures from their main table (Table 4, pages 482-484), pool the cases for non-partisan and retention election systems, and compare the pooled set of cases with the partisan cases, we obtain Table 15 below.

The bottom line is again reasonably clear. Conditional on a judge being disciplined for malfeasance, for each of the following items the percentage of cases involving the item is significantly higher in partisan systems: criminal findings, "serious" findings, multiple violations in one case, lack of impartiality, arrogant behavior, and deceitful behavior. For one item, neglect of duties, the proportion of cases involving the item is significantly lower in partisan systems. There is no significant difference between partisan and non-partisan/retention election systems on two items: cases involving improper political activity, and judges with multiple cases.

The figures presented in this section are only correlations, and cannot be given a causal interpretation. They are suggestive nonetheless.

\section{Conclusion}

This paper analyzed how the institutional design of electoral processes shape voters' decisions to vote and the influence of party affiliation and candidate quality on election outcomes. Partisan elections may be a good idea for some types of public offices, especially those offices with a large ideological, policy-making component. However, making elections partisan may have an adverse effect in that partisanship crowds out the influence of candidate quality. If voters make their decisions mainly on the basis of party - or ideology, or ethnicity, race, or religion - then they might elect low-quality officials with the "right" party or ideology over high-quality politicians with the "wrong" party or ideology.

\footnotetext{
${ }^{34}$ We do not have the 2009 survey results.

${ }^{35}$ Lim (2012) proposes a reason why appointed judges may be of better quality than elected judges. Reelection concerns imposed by the election system may have the perverse effect of discouraging public officials with a high level of human capital from holding office. Due to reelection concerns, the welfare level of elected judges is much lower than that of appointed judges, making judges with a high level of human capital less interested in the job.
} 
Trial court judges do not have a large policy-making role, and it is not clear that party considerations should loom large. Evidently, however, when party labels are on the ballot, voters rely heavily on these labels when voting. This cannot be explained by clear partisan differences in sentencing. More likely, it is due to the fact that the partisan cue is so easy to use. More importantly, we find evidence that the relative quality of candidates has less effect on voting outcomes in partisan elections than in non-partisan elections. This suggests that partisan elections might be a bad idea for public officials who perform relatively bureaucratic, less ideological tasks. Our findings on turnout rates are also consistent with these findings. The turnout rate is highest in partisan elections, followed by non-partisan and retention elections. Additional sources of information about candidates have an effect on turnout only in non-partisan competitive elections.

Finally, our study can be extended to analyze the following issues. First, holding non-partisan primaries at the same time as regular partisan primaries strikes us as a bad, at least in principle, because the electorate is often highly skewed depending on which party has highly contested primaries at the top of the ticket. How much of problem is this in practice? Second, how does candidate quality interact with factors such as race and gender, and how does this differ across electoral systems? Third, to what extent does partisan voting behavior affects selecting high-quality public officials for other low-information offices, such as regulators? Careful studies of these issues will help us improve understanding of electoral processes. 


\section{References}

Alesina, Alberto and Guido Tabellini. 2007. "Bureaucrats or Politicians? Part I: A Single Policy Task." American Economic Review 97:169-79.

Ashworth, Scott and Ethan Bueno de Mesquita. 2008. "Electoral Selection, Strategic Challenger Entry, and the Incumbency Advantage." Journal of Politics 70 (4):1006-1025.

Aspin, Larry T. and William K. Hall. 1989. "Friends and Neighbors Voting in Judicial Retention Elections: A Research Note Comparing Trial and Appellate Court Elections." Western Political Quarterly 42:587-596.

Banerjee, Abhijit V. and Rohini Pande. 2007. "Parochial Politics: Ethnic Competition and Politician Corruption in India." Working Paper.

Barber, Kathleen L. 1971. "Ohio Judicial Elections - Non-Partisan Premises with Partisan Results." Ohio State Law Journal 32:762-789.

Barro, Robert J. 1973. "The Control of Politicians: An Economic Model." Public Choice 14:19-42.

Bartels, Larry M. 2008. "The Irrational Electorate." Wilson Quarterly 32 (4):44-50.

Besley, Timothy J. and Stephen Coate. 2003. "Elected Versus Appointed Regulators: Theory and Evidence." Journal of the European Economic Association 1 (5):1176-1206.

Besley, Timothy J., Rohini Pande, and Vijayendra Rao. 2005. "Political Selection and the Quality of Government: Evidence from South India." Working Paper.

Besley, Timothy J., Torsten Persson, and Daniel M. Sturm. 2010. "Political Competition, Policy and Growth: Theory and Evidence from the United States." Review of Economic Studies 77 (4):13291352 .

Blume, John and Theodore Eisenberg. 1999. "Judicial Politics, Death Penalty Appeals, and Case Selection: An Empirical Study." Southern California Law Review 72:464-503.

Bonneau, Chris W. and Melinda G. Hall. 2009. In Defense of Judicial Elections. Routeledge.

Champagne, Anthony and Greg Thielemann. 1991. "Awareness of Trial Court Judges." Judicature 74:271-276.

Coate, Stephen and Michael Conlin. 2004. "A Group Rule-Utilitarian Approach to Voter Turnout: Theory and Evidence." The American Economic Review 94 (5):1476-1504.

Downs, Anthony. 1957. An Economic Theory of Democracy. Harper and Row.

Dubois, Philip L. 1980. From Ballot to Bench: Judicial Elections and the Quest for Accountability. Austin: University of Texas Press. 
- 1984. "Voting Cues in Non-Partisan Trial Court Elections: A Multivariate Assessment." Law $\&$ Society Review 18:395-436.

Feddersen, Timothy J. and Wolfgang Pesendorfer. 1996. "The Swing Voter's Curse." American Economic Review 86 (3):408-424.

Ferejohn, John. 1986. "Incumbent Performance and Electoral Control." Public Choice 50:5-26.

Gelman, Andrew, James S. Liebman, Valerie West, and Alexander Kiss. 2004. "A Broken System:

The Persistent Patterns of Reversals of Death Sentences in the United States." Journal of Empirical Legal Studies 1 (2):209-261.

Goldschmidt, Jona, David Olson, and Margaret Ekman. 2008-2009. "The Relationship between Method of Judicial Selection and Judicial Misconduct." Widener Law Journal 18.

Goldstein, Joel H. 1980. "Bar Poll Ratings as the Leading Influence on a Non-Partisan Judicial Election." Judicature 63:377-384.

Gordon, Sanford C. and Gregory A. Huber. 2007. "The Effect of Electoral Competitiveness on Incumbent Behavior." Quarterly Journal of Political Science 2 (2):107-138.

Hall, Melinda Gann. 2001. "State Supreme Courts in American Democracy: Probing the Myths of Judicial Reform." American Political Science Review 95 (2):315-330.

Klein, David and Lawrence Baum. 2001. "Ballot Information and Voting Decisions in Judicial Elections." Political Research Quarterly 54 (4):709-728.

Lim, Claire S.H. 2012. "Preferences and Incentives of Appointed and Elected Public Officials: Evidence from State Trial Court Judges." Forthcoming in the American Economic Review.

Lim, Claire S.H., James M. Snyder, Jr., and David Strömberg. 2012. "The Judge, The Politician, and the Press: Newspaper Coverage and Criminal Sentencing Across Electoral Systems." Working Paper.

McGraw, Kathleen M. 2003. "Political Impressions, Formation and Management." Oxford Handbook of Political Psychology .

McKnight, R. Neal, Roger Schaefer, and Charles A. Johnson. 1978. "Choosing Judges: Do the Voters Know What They're Doing?" Judicature 62:94-99.

Padro i Miquel, Gerard. 2007. "The Control of Politicians in Divided Societies: The Politics of Fear." Review of Economic Studies 74 (4):1259-1274.

Reid, Traciel V. and Robert S. Moog. 2011. "Voter Information, Voter Participation, and the North Carolina Judicial Election Reforms: The Views of the Voters." Politics E Policy 39 (2):223-250. 
Sheldon, Charles H. 1977. "Influencing the Selection of Judges: The Variety and Effectiveness of State Bar Activities." Western Political Quarterly 30 (3):397-400.

Squire, Peverill and Eric R.A.N. Smith. 1988. "The Effect of Partisan Information on Voters in Non-Partisan Elections." Journal of Politics 50 (1):168-179.

Stumpf, Harry P. and John H. Culver. 1992. The Politics of State Courts. New York: Longman.

Tabarrok, Alexander and Eric Helland. 1999. "Court Politics : The Political Economy of Tort Awards." Journal of Law and Economics 42 (1):157-88.

Volcansek, Mary L. 1981. "An Exploration of the Judicial Election Process." Western Political Quarterly 34 (4):572-577. 
TABLE 1

Selection and Retention Rules for the State Trial Courts

\begin{tabular}{|c|c|c|c|}
\hline No. of States & Initial Selection & Re-election & Set of States \\
\hline 9 & Partisan Election & Partisan Election & $\begin{array}{l}\mathrm{AL}, \mathrm{IN}, \mathrm{KS}, \mathrm{LA}, \mathrm{MO} \\
\mathrm{NY}, \mathrm{TN}, \mathrm{TX}, \mathrm{WV}\end{array}$ \\
\hline 22 & Non-partisan Election & Non-partisan Election & $\begin{array}{c}\mathrm{AR}, \mathrm{AZ}, \mathrm{CA}, \mathrm{FL}, \mathrm{GA} \\
\mathrm{ID}, \mathrm{IN}, \mathrm{KY}, \mathrm{MD}, \mathrm{MI} \\
\mathrm{MN}, \mathrm{MS}, \mathrm{MT}, \mathrm{NV} \\
\text { NC, ND, OH, OK } \\
\text { OR, SD, WA, WI }\end{array}$ \\
\hline 3 & Partisan Election & Retention Election & IL, NM, PA \\
\hline 10 & Appointment & Retention Election & $\begin{array}{l}\text { AZ, AK, CO, IA, IN, } \\
\mathrm{KS}, \mathrm{MO}, \mathrm{NE}, \mathrm{UT}, \mathrm{WY}\end{array}$ \\
\hline 11 & \multicolumn{2}{|c|}{ Appointment } & $\begin{array}{l}\mathrm{CT}, \mathrm{DE}, \mathrm{HI}, \mathrm{ME} \\
\mathrm{MA} \mathrm{NH}, \mathrm{NJ}, \mathrm{RI} \\
\quad \mathrm{SC}, \mathrm{VA}, \mathrm{VT}\end{array}$ \\
\hline
\end{tabular}

Note 1: The classification is based on the selection and retention rule for the state trial courts of general jurisdiction. Most of the states have the same selection rule for all levels of the state court.

Note 2: The selection systems can be divided into five groups. There are four states (Arizona, Indiana, Kansas, and Missouri) that have a within-state variation of two different systems (partisan or non-partisan election and appointment-retention election) at the district level. These states are included in both categories. For more details, see the website on judicial selection systems by the American Judicature Society (http://www.judicialselection.us/). In New Mexico judges are first appointed by the governor, then they must run in a partisan election, and subsequent elections are retention elections. In Maryland, circuit judges appointed by the governor must run in the next major election cross-filed in the Democratic and Republican primaries without party labels. If there are different winners in each primary, they will face off in the general election.

Note 3: We classify a state as having non-partisan elections if party labels do not appear on the general election ballot. In Arizona (in some counties), Maryland, and Ohio, nominations are partisan but the general election ballot is non-partisan.

Source: Lim, Snyder, and Strömberg (2012). 
TABLE 2

Distribution of Candidate-Race Observations in the Election Data

\begin{tabular}{|c|c|c|c|c|c|c|c|c|c|}
\hline \multirow[b]{3}{*}{ State } & \multirow{3}{*}{$\begin{array}{l}\text { Main } \\
\text { Selection } \\
\text { System }\end{array}$} & \multicolumn{7}{|c|}{ Number of Observations by Level and Election Period } & \multirow[b]{3}{*}{ Period } \\
\hline & & \multicolumn{2}{|c|}{ Supreme } & \multicolumn{2}{|c|}{ Appellate } & \multicolumn{2}{|c|}{ Trial } & \multirow[b]{2}{*}{ Total } & \\
\hline & & Primary & General & Primary & General & Primary & General & & \\
\hline AK & Appt + Ret & 0 & 18 & 0 & 11 & 0 & 153 & 182 & $1976-2010$ \\
\hline $\mathrm{AL}$ & Partisan & 28 & 56 & 70 & 53 & 278 & 574 & 1059 & $1992-2010$ \\
\hline $\mathrm{AR}$ & Non-partisan & 25 & 14 & 32 & 7 & 192 & 46 & 316 & $1992-2010$ \\
\hline $\mathrm{AZ}$ & Non-partisan & 0 & 19 & 0 & 76 & 67 & 528 & 690 & $1990-2010$ \\
\hline $\mathrm{CA}$ & Non-partisan & 0 & 20 & 0 & 280 & 936 & 234 & 1470 & $1990-2010$ \\
\hline $\mathrm{CO}$ & Appt + Ret & 0 & 13 & 0 & 33 & 0 & 334 & 380 & $1996-2010$ \\
\hline FL & Non-partisan & 0 & 39 & 0 & 321 & 1144 & 262 & 2990 & $1978-2010$ \\
\hline GA & Non-partisan & 17 & 19 & 34 & 43 & 655 & 670 & 1438 & $1996-2010$ \\
\hline IA & Appt + Ret & 0 & 19 & 0 & 28 & 0 & 744 & 791 & $1990-2010$ \\
\hline ID & Non-partisan & 26 & 2 & 11 & 0 & 168 & 8 & 215 & $1990-2010$ \\
\hline IL & Part + Ret & 51 & 36 & 285 & 184 & 2722 & 2819 & 6097 & $1982-2010$ \\
\hline IN & Partisan & 0 & 5 & 0 & 17 & 669 & 604 & 1295 & $2002-2010$ \\
\hline KS & Mixed & 0 & 28 & 0 & 62 & 668 & 1196 & 1954 & $1982-2010$ \\
\hline KY & Appt + Ret & 3 & 21 & 12 & 50 & 78 & 433 & 597 & $1999-2010$ \\
\hline LA & Partisan & 32 & 7 & 139 & 13 & 1078 & 143 & 1412 & $1996-2010$ \\
\hline MD & Non-partisan & 0 & 12 & 0 & 35 & 588 & 251 & 886 & $1990-2008$ \\
\hline MI & Non-partisan & 0 & 61 & 50 & 131 & 309 & 886 & 1437 & $1992-2010$ \\
\hline $\mathrm{MN}$ & Non-partisan & 13 & 26 & 0 & 49 & 95 & 789 & 972 & $1990-2010$ \\
\hline $\mathrm{MO}$ & Partisan & 0 & 9 & 0 & 52 & 250 & 432 & 743 & $1996-2010$ \\
\hline MS & Non-partisan & 24 & 39 & 0 & 40 & 0 & 136 & 239 & $1986-2000$ \\
\hline $\mathrm{MT}$ & Non-partisan & 31 & 32 & 0 & 0 & 215 & 179 & 457 & $1992-2010$ \\
\hline $\mathrm{NC}$ & Non-partisan & 13 & 38 & 36 & 60 & 69 & 294 & 510 & $1994-2010$ \\
\hline ND & Non-partisan & 17 & 17 & 0 & 0 & 222 & 192 & 448 & $1990-2010$ \\
\hline $\mathrm{NE}$ & Appt + Ret & 0 & 24 & 0 & 18 & 0 & 175 & 217 & $1990-2010$ \\
\hline NM & Part + Ret & 7 & 19 & 24 & 33 & 170 & 334 & 587 & $1996-2010$ \\
\hline $\mathrm{NV}$ & Non-partisan & 22 & 29 & 0 & 0 & 262 & 200 & 513 & $1998-2010$ \\
\hline NY & Partisan & 0 & 0 & 0 & 0 & 0 & 1144 & 1144 & $1990-2008$ \\
\hline $\mathrm{OH}$ & Non-partisan & 60 & 54 & 483 & 380 & 2143 & 1824 & 4944 & $1990-2010$ \\
\hline OK & Non-partisan & 0 & 36 & 0 & 69 & 641 & 400 & 1146 & $1990-2010$ \\
\hline OR & Non-partisan & 41 & 10 & 37 & 15 & 696 & 193 & 992 & $1990-2010$ \\
\hline PA & Part + Ret & 16 & 17 & 56 & 53 & 1074 & 492 & 1708 & 1991-2011 \\
\hline SD & Non-partisan & 0 & 9 & 0 & 0 & 24 & 107 & 140 & $1990-2006$ \\
\hline $\mathrm{TN}$ & Partisan & 0 & 6 & 0 & 36 & 0 & 254 & 296 & $2000-2010$ \\
\hline $\mathrm{TX}$ & Partisan & 94 & 86 & 668 & 495 & 3475 & 2713 & 7531 & $1990-2010$ \\
\hline UT & Appt + Ret & 0 & 10 & 0 & 26 & 0 & 229 & 265 & $1990-2010$ \\
\hline WA & Non-partisan & 154 & 92 & 103 & 95 & 504 & 268 & 1216 & $1970-2010$ \\
\hline WI & Non-partisan & 18 & 28 & 9 & 72 & 474 & 1041 & 1642 & $1988-2010$ \\
\hline WV & Partisan & 33 & 19 & 0 & 0 & 296 & 218 & 566 & $1992-2010$ \\
\hline WY & Appt + Ret & 0 & 12 & 0 & 0 & 0 & 56 & 68 & $1996-2010$ \\
\hline Total & & 725 & 1001 & 2049 & 2837 & 20162 & 21555 & 49553 & \\
\hline
\end{tabular}

Note: When a state has primary-runoffs (general-runoffs), we count them as primaries (general elections) in this table. Since primary-runoffs and general-runoffs are rare, this classification does not affect the picture of our data in a meaningful way. There are states with variation in selection systems across different levels of courts. In the case of such variation, we put the main selection system for the state trial courts. "Appt + Retention" refers to states with appointment and retention systems. "Part + Ret" refers to states with partisan elections followed by retention elections. "Mixed" refers to a case of within-state, cross-district variation. The total number for Florida includes 1224 observations of unopposed candidate-races that are not classified as primary or general elections. 
TABLE 3

Summary Statistics of Partisan and Non-Partisan Elections

\begin{tabular}{llcccc}
\hline \hline & & \multicolumn{2}{c}{ Partisan Elections } & \multicolumn{2}{c}{ Non-Partisan Elections } \\
\cline { 2 - 6 } & & $\begin{array}{c}\text { Primary } \\
(1)\end{array}$ & $\begin{array}{c}\text { General } \\
(2)\end{array}$ & $\begin{array}{c}\text { 1st Round } \\
(3)\end{array}$ & $\begin{array}{c}\text { 2nd Round } \\
(4)\end{array}$ \\
\hline No. of States & \multicolumn{2}{c}{17} & \multicolumn{2}{c}{23} \\
No. of Seats up for Election & \multicolumn{2}{c}{7817} & \multicolumn{2}{c}{11019} \\
\hline Total No. of Races & & 8956 & 6020 & 9280 & 2619 \\
\hline No. of Uncontested Races & & 6629 & 4131 & 6862 & $1067^{\text {a }}$ \\
No. of Contested Races & & 2327 & 1889 & 2418 & 1552 \\
\hline No. of Candidates in & Mean & 2.8 & 2.0 & 2.8 & 2.0 \\
Contested Elections & S.D. & 1.4 & 0.2 & 1.3 & 0.2 \\
\hline Winners' Vote Share in & Mean & .529 & .567 & .560 & .578 \\
Contested Elections & S.D. & .145 & .074 & .120 & .070 \\
\hline
\end{tabular}

a The number of uncontested races in the second round of nonpartisan elections only includes Arizona, Maryland, and Ohio, which have election rules that are different from standard non-partisan elections. There are states in which candidates who won the first round with majority votes appear on the ballot again in general elections and win automatically. This number does not include such races. Therefore, competitiveness of second-round races in non-partisan elections should not be directly compared with partisan general elections. 
TABLE 4

Statistics of Retention Elections

\begin{tabular}{|c|c|}
\hline $\begin{array}{l}\text { No. of States } \\
\text { No. of Elections }\end{array}$ & $\begin{array}{c}20 \\
6505\end{array}$ \\
\hline \multicolumn{2}{|c|}{ Share of Yes-Votes } \\
\hline Mean & 0.739 \\
\hline Std. Dev. & 0.067 \\
\hline Minimum & 0.326 \\
\hline 10th percentile & 0.646 \\
\hline Median & 0.747 \\
\hline 90th percentile & 0.817 \\
\hline Maximum & 0.916 \\
\hline
\end{tabular}


TABLE 5

Summary of Judicial Evaluations Data

\begin{tabular}{|c|c|c|c|c|}
\hline State & Type & Name of Evaluating Body & Period & Number \\
\hline AK & State & Alaska Judicial Council & $1996-2010$ & 152 \\
\hline $\mathrm{AL}$ & Bar & Birmingham Bar Association & $2004-2010$ & 118 \\
\hline $\mathrm{AZ}$ & State & Arizona Commiss. on Judicial Performance Review & $2000-2010$ & 384 \\
\hline $\mathrm{CA}$ & Bar & Los Angeles County Bar Association & $1994-2010$ & 314 \\
\hline $\mathrm{CA}$ & Bar & Orange County Bar Association & $1998-2010$ & 65 \\
\hline $\mathrm{CA}$ & Bar & San Diego County Bar Association & $1994-2010$ & 98 \\
\hline $\mathrm{CA}$ & Bar & San Francisco County Bar Association & $1996-2010$ & 21 \\
\hline $\mathrm{CO}$ & State & Colorado Commiss. on Judicial Performance & $1996-2010$ & 781 \\
\hline FL & Bar & Dade County Bar Association & $2001-2010$ & 487 \\
\hline IL & Bar & Illinois State Bar Association & $1990-2010$ & 3501 \\
\hline IL & Bar & Chicago area Bar Associations (several) & $1990-2010$ & 2619 \\
\hline IA & Bar & Iowa State Bar Association & $1990-2010$ & 803 \\
\hline KS & State & Kansas Commission on Judicial Performance & $2008-2010$ & 127 \\
\hline KY & Bar & Louisville Bar Association & $2003-2010$ & 98 \\
\hline MI & Bar & Detroit Metropolitan Bar Association & $1992-2010$ & 354 \\
\hline MN & Bar & State Bar Association (with 2 county Bar Assoc) & $1990-2010$ & 190 \\
\hline MO & Bar & Missouri Bar Association & 1996-2006 & 293 \\
\hline $\mathrm{NE}$ & Bar & Nebraska State Bar Association & $2002-2010$ & 694 \\
\hline NM & State & New Mexico Judicial Perform. Eval. Commiss. & $2002-2010$ & 194 \\
\hline NV & News & Las Vegas Review Journal & $2000-2011$ & 408 \\
\hline NY & Bar & New York City Bar Association & $1997-2010$ & 322 \\
\hline $\mathrm{OH}$ & Bar & Cleveland area Bar Associations (several) & $1992-2010$ & 769 \\
\hline $\mathrm{OH}$ & Bar & Columbus Bar Association & $1993-2010$ & 628 \\
\hline OR & Bar & Oregon State Bar Association & $1990-2010$ & 913 \\
\hline PA & Bar & Philadelphia Bar Association & 1991-2011 & 768 \\
\hline $\mathrm{PA}$ & Bar & Allegheny County Bar Association & 2001-2009 & 167 \\
\hline $\mathrm{TX}$ & Bar & Houston Bar Association & $1992-2010$ & 1959 \\
\hline $\mathrm{TX}$ & Bar & Dallas Bar Association & $1993-2011$ & 1550 \\
\hline $\mathrm{UT}$ & State & Utah Judicial Council & $1998-2010$ & 223 \\
\hline WA & Bar & Seattle-King County Bar Association & $1990-2012$ & 425 \\
\hline WY & Bar & Wyoming State Bar Association & $1998-2010$ & 87 \\
\hline
\end{tabular}


TABle 6

Estimates of Partisan Voting Using Precinct Level Data

\begin{tabular}{|c|c|c|c|c|c|c|}
\hline State & Area & Election Type & Court Type & Party Determination ${ }^{\mathrm{a}}$ & $\mathrm{N}$ & Avg Corr \\
\hline $\mathrm{IL}^{\mathrm{b}}$ & Cook County & Partisan & trial & on ballot & 8 & 0.91 \\
\hline $\mathrm{NC}$ & State & Partisan & trial & on ballot & 49 & 0.93 \\
\hline $\mathrm{NC}$ & State & Partisan & appellate & on ballot & 20 & 0.97 \\
\hline PA & Philadelphia County & Partisan & trial & on ballot & 11 & 0.88 \\
\hline PA & Philadelphia County & Partisan & appellate & on ballot & 7 & 0.94 \\
\hline TX & State & Partisan & trial & on ballot & 61 & 0.99 \\
\hline $\mathrm{TX}$ & State & Partisan & appellate & on ballot & 32 & 0.99 \\
\hline $\mathrm{OH}$ & Hamilton County & Nonpartisan & trial & partisan primary & 16 & 0.89 \\
\hline $\mathrm{OH}$ & Hamilton County & Nonpartisan & appellate & partisan primary & 19 & 0.92 \\
\hline $\mathrm{AR}$ & State & Nonpartisan & trial & maximum possible & 27 & 0.31 \\
\hline $\mathrm{CA}$ & San Diego County & Nonpartisan & trial & maximum possible & 12 & 0.45 \\
\hline ID & State & Nonpartisan & trial & maximum possible & 3 & 0.33 \\
\hline $\mathrm{NC}$ & State & Nonpartisan & trial & previous election $^{\mathrm{c}}$ & 151 & 0.28 \\
\hline $\mathrm{NC}$ & State & Nonpartisan & trial & maximum possible & 151 & 0.55 \\
\hline WA & King County & Nonpartisan & trial & maximum possible & 16 & 0.45 \\
\hline $\mathrm{AZ}$ & Maricopa County & Retention, D & trial & appointing governor & 74 & 0.17 \\
\hline $\mathrm{AZ}$ & Maricopa County & Retention, $\mathrm{R}$ & trial & appointing governor & 126 & 0.06 \\
\hline $\mathrm{AZ}$ & Maricopa County & Retention, D & trial & registration/groups & 30 & 0.40 \\
\hline $\mathrm{AZ}$ & Maricopa County & Retention, $\mathrm{R}$ & trial & registration/groups & 16 & 0.02 \\
\hline $\mathrm{CA}$ & San Diego County & Retention, D & appellate & appointing governor & 9 & 0.53 \\
\hline $\mathrm{CA}$ & San Diego County & Retention, $\mathrm{R}$ & appellate & appointing governor & 14 & 0.26 \\
\hline $\mathrm{CO}$ & State & Retention, D & appellate & appointing governor & 7 & 0.17 \\
\hline IL & Cook County & Retention, D & trial & 1st election & 110 & 0.37 \\
\hline IL & Cook County & Retention, $\mathrm{R}$ & trial & 1st election & 18 & 0.28 \\
\hline IL & Logan County & Retention, $\mathrm{R}$ & trial & 1st election & 8 & -0.23 \\
\hline
\end{tabular}

${ }^{a}$ In nonpartisan elections, party affiliation is not shown on the ballot. Thus, we cannot exactly determine party affiliation in most cases. In such cases, we code party affiliation of candidates to maximize correlation ("maximum possible"). For example, if candidate A's vote share increases and candidate B's vote share decreases as Democratic Normal Vote increases, we regard that candidate A is Democrat and candidate B is Republican.

${ }^{\mathrm{b}}$ In Illinois, judges are initially elected in partisan elections. Then, when their term expires, they run for retention election.

${ }^{\mathrm{c}}$ North Carolina changed its judicial selection system from partisan to nonpartisan election. The change took effect in 1998 for trial court judges, and in 2004 for appellate and supreme court judges. Thus, we can determine the party affiliation of many judges in North Carolina based on records of partisan elections. 
TABLE 7

Retention Elections in Cook County

\begin{tabular}{|c|c|c|c|c|c|c|c|c|c|c|}
\hline \multirow[b]{2}{*}{ Circuit } & \multirow[b]{2}{*}{ Party } & \multicolumn{3}{|c|}{ Correlation } & \multicolumn{6}{|c|}{ Share of Yes-Votes } \\
\hline & & $\mathrm{N}$ & Mean & $\mathrm{SD}$ & $\mathrm{N}$ & Mean & $\mathrm{SD}$ & $\begin{array}{c}10 \text { th } \\
\text { percentile }\end{array}$ & $\begin{array}{l}\text { med } \\
\text {-ian }\end{array}$ & $\begin{array}{c}\text { 90th } \\
\text { percentile }\end{array}$ \\
\hline \multirow{2}{*}{ At large } & $\mathrm{D}$ & 49 & .33 & .14 & 117831 & 77.3 & 6.8 & 69.9 & 77.6 & 85.0 \\
\hline & $\mathrm{R}$ & 1 & .06 & & 2448 & 74.2 & 5.3 & 67.6 & 74.1 & 81.3 \\
\hline \multirow{2}{*}{ Sub-circuits } & $\mathrm{D}$ & 57 & .41 & .16 & 137472 & 74.7 & 8.5 & 64.8 & 75.7 & 84.0 \\
\hline & $\mathrm{R}$ & 16 & .28 & .18 & 38673 & 74.9 & 7.7 & 66.3 & 75.7 & 83.2 \\
\hline
\end{tabular}


TABLE 8

Percentage of Winners By Recommended/Not-Recommended Status

\begin{tabular}{|c|c|c|c|c|c|c|}
\hline \multirow[t]{2}{*}{ State } & \multicolumn{2}{|c|}{ Score $=0$} & \multicolumn{2}{|c|}{ Score $=1$} & \multicolumn{2}{|c|}{$\begin{array}{l}\% \text { of Winners } \\
\text { with Score }=1\end{array}$} \\
\hline & Mean & \# Obs & Mean & \# Obs & Mean & \# Obs \\
\hline \multicolumn{7}{|c|}{ Partisan Primary Elections } \\
\hline Illinois & 24.5 & {$[709]$} & 53.4 & {$[1308]$} & 80.0 & {$[872]$} \\
\hline Texas & 49.0 & [208] & 79.1 & {$[589]$} & 82.0 & {$[568]$} \\
\hline Ohio & 43.4 & {$[129]$} & 71.3 & {$[296]$} & 79.0 & {$[267]$} \\
\hline \multicolumn{7}{|c|}{ Partisan General Elections } \\
\hline Illinois & 58.7 & {$[172]$} & 76.7 & {$[696]$} & 84.1 & {$[635]$} \\
\hline Texas & 43.6 & {$[94]$} & 60.1 & {$[436]$} & 86.5 & {$[303]$} \\
\hline \multicolumn{7}{|c|}{ Non-Partisan Elections (Primary and General) } \\
\hline California & 23.0 & {$[113]$} & 57.1 & {$[340]$} & 88.2 & {$[220]$} \\
\hline Minnesota & 9.5 & {$[42]$} & 71.8 & {$[78]$} & 93.3 & {$[60]$} \\
\hline Oregon & 19.5 & {$[82]$} & 61.7 & {$[128]$} & 83.2 & {$[95]$} \\
\hline Washington & 22.5 & {$[40]$} & 59.4 & {$[207]$} & 93.2 & {$[132]$} \\
\hline Wisconsin & 37.0 & {$[27]$} & 64.9 & {$[74]$} & 82.8 & {$[58]$} \\
\hline Ohio & 29.0 & {$[69]$} & 68.1 & {$[383]$} & 92.9 & {$[281]$} \\
\hline
\end{tabular}

Note: All candidates with bar association scores are shown. $0=$ Not Recommended, 1=Recommended. Robust standard errors are in parentheses, and the numbers of observations are in brackets. The columns denoted "Mean" gives the overall means of the dependent variables for each sample. 
TABLE 9

Effect of Score on Election Outcomes

\begin{tabular}{|c|c|c|c|c|c|c|c|c|}
\hline \multirow[t]{2}{*}{ State } & \multicolumn{4}{|c|}{ Win Percentage } & \multicolumn{4}{|c|}{ Vote Percentage } \\
\hline & Mean & $\begin{array}{l}\text { Coef } \\
(1) \\
\end{array}$ & $\begin{array}{c}\text { Std Error } \\
(2)\end{array}$ & $\begin{array}{c}\text { \# Obs } \\
(3) \\
\end{array}$ & Mean & $\begin{array}{c}\text { Coef } \\
(4) \\
\end{array}$ & $\begin{array}{c}\text { Std Error } \\
(5) \\
\end{array}$ & $\begin{array}{c}\text { \# Obs } \\
(6) \\
\end{array}$ \\
\hline \multicolumn{9}{|c|}{ Partisan General Elections } \\
\hline Illinois & 56.4 & 4.5 & $(5.1)$ & {$[227]$} & 52.9 & 0.9 & $(0.9)$ & {$[226]$} \\
\hline Texas & 44.9 & 1.7 & $(4.6)$ & {$[243]$} & 46.0 & 2.1 & $(0.7)$ & {$[243]$} \\
\hline \multicolumn{9}{|c|}{ Partisan Primary Elections } \\
\hline Illinois & 49.4 & 30.0 & $(4.8)$ & {$[170]$} & 48.6 & 9.5 & $(1.4)$ & {$[169]$} \\
\hline Texas & 49.2 & 24.4 & $(6.0)$ & {$[122]$} & 50.3 & 10.5 & $(1.8)$ & {$[122]$} \\
\hline Ohio & 65.7 & 23.4 & $(10.7)$ & {$[35]$} & 53.7 & 11.9 & $(3.1)$ & {$[35]$} \\
\hline \multicolumn{9}{|c|}{ Non-Partisan Elections } \\
\hline California & 37.2 & 38.0 & $(6.0)$ & {$[113]$} & 48.2 & 12.4 & $(1.8)$ & {$[113]$} \\
\hline Minnesota & 46.3 & 47.4 & $(5.7)$ & {$[54]$} & 49.5 & 10.8 & $(1.1)$ & {$[49]$} \\
\hline Oregon & 44.7 & 29.7 & $(12.4)$ & {$[47]$} & 48.8 & 7.2 & $(2.3)$ & {$[47]$} \\
\hline Washington & 50.8 & 42.5 & $(10.3)$ & {$[63]$} & 49.9 & 16.3 & $(2.7)$ & {$[63]$} \\
\hline Wisconsin & 48.6 & 34.1 & $(11.3)$ & {$[37]$} & 50.9 & 11.8 & $(3.0)$ & {$[37]$} \\
\hline Ohio & 61.7 & 28.8 & $(5.9)$ & {$[162]$} & 53.1 & 7.0 & $(1.3)$ & {$[163]$} \\
\hline \multicolumn{9}{|c|}{ Retention Elections } \\
\hline Arizona & 100.0 & 0.0 & $(0.0)$ & {$[332]$} & 72.5 & 14.8 & $(3.4)$ & {$[331]$} \\
\hline Colorado & 98.5 & 65.8 & $(6.1)$ & {$[333]$} & 71.9 & 20.2 & $(2.8)$ & {$[605]$} \\
\hline Illinois & 98.8 & 19.7 & $(1.4)$ & {$[1202]$} & 76.9 & 10.1 & $(0.7)$ & {$[1202]$} \\
\hline Iowa & 99.9 & 14.3 & $(1.3)$ & {$[741]$} & 74.8 & 9.7 & $(1.9)$ & {$[741]$} \\
\hline Kansas & 100.0 & 0.0 & $(0.0)$ & {$[111]$} & 71.7 & 0.6 & $(2.9)$ & {$[111]$} \\
\hline Missouri & 100.0 & 0.0 & $(0.0)$ & [291] & 68.1 & 6.3 & $(1.4)$ & {$[290]$} \\
\hline Nebraska & 99.5 & 10.0 & $(2.1)$ & {$[222]$} & 72.1 & 9.6 & $(1.4)$ & {$[222]$} \\
\hline New Mexico & 96.6 & 57.1 & $(4.8)$ & {$[117]$} & 74.1 & 24.4 & $(1.9)$ & {$[117]$} \\
\hline Utah & 99.0 & 28.6 & $(3.3)$ & {$[200]$} & 80.3 & 15.0 & $(1.8)$ & {$[200]$} \\
\hline Wyoming & 100.0 & 0.0 & $(0.0)$ & {$[71]$} & 77.8 & 11.3 & $(1.8)$ & {$[71]$} \\
\hline
\end{tabular}

Note: Each cell in columns (1)-(6) shows the estimated coefficient on the variable Relative Score, as well as the standard error (in parentheses) and the number of observations (in brackets). 
TABLE 10

Partisan and Ideological Differences Among Voters

\begin{tabular}{lcccc}
\hline \hline Year & Appointed & Retention & Nonpartisan & Partisan \\
\hline Partisan Intensity & 1.70 & 1.89 & 1.86 & 1.89 \\
& {$[1851]$} & {$[1363]$} & {$[6244]$} & {$[3991]$} \\
Ideological Extremity & 1.10 & 1.10 & 1.11 & 1.08 \\
& {$[1420]$} & {$[1050]$} & {$[4431]$} & {$[2700]$} \\
Ideological Warmth Extremity & 22.6 & 22.4 & 22.1 & 21.2 \\
& {$[1624]$} & {$[1206]$} & {$[5387]$} & {$[3410]$} \\
\hline
\end{tabular}


TABLE 11

Partisanship and Sentencing

\begin{tabular}{|c|c|c|c|c|}
\hline \multicolumn{5}{|c|}{$\begin{array}{l}\text { Dependent Variable: Relative Harshness of Sentence } \\
\text { Independent Variable: Share of Democratic Judges }\end{array}$} \\
\hline $\begin{array}{l}\text { Offense } \\
\text { Category }\end{array}$ & $\begin{array}{l}\text { Parameter } \\
\text { Estimate }\end{array}$ & Std Error & $N$ & $R^{2}$ \\
\hline \multicolumn{5}{|c|}{ Texas, All Districts } \\
\hline Violent & 0.037 & 0.016 & 24941 & 0.32 \\
\hline Property & -0.014 & 0.017 & 38400 & 0.39 \\
\hline Drug & -0.040 & 0.010 & 51566 & 0.44 \\
\hline Other & -0.039 & 0.019 & 22686 & 0.44 \\
\hline \multicolumn{5}{|c|}{ Texas, Smaller Districts Only } \\
\hline Violent & 0.044 & 0.082 & 1984 & 0.39 \\
\hline Property & -0.098 & 0.067 & 3043 & 0.43 \\
\hline Drug & 0.077 & 0.041 & 3334 & 0.48 \\
\hline Other & 0.096 & 0.050 & 1890 & 0.37 \\
\hline \multicolumn{5}{|c|}{ Other States, All Districts } \\
\hline Violent & -0.036 & 0.025 & 28849 & 0.28 \\
\hline Property & -0.009 & 0.025 & 54284 & 0.31 \\
\hline Drug & -0.023 & 0.014 & 106403 & 0.39 \\
\hline Other & -0.068 & 0.026 & 41386 & 0.30 \\
\hline \multicolumn{5}{|c|}{ Other States, Smaller Districts Only } \\
\hline Violent & -0.106 & 0.075 & 3505 & 0.39 \\
\hline Property & -0.019 & 0.076 & 7532 & 0.37 \\
\hline Drug & -0.029 & 0.035 & 9710 & 0.42 \\
\hline Other & -0.096 & 0.054 & 3830 & 0.39 \\
\hline
\end{tabular}

Note: In each panel the coefficient estimates are from four separate regressions, one for each offense category. Control variables are: demographic composition of the population (race, gender, ethnicity, age), income, and crime rates. Other states are: Alabama, Illinois, Indiana, Kansas, Louisiana, New Mexico, and Ohio. 
TABLE 12

Relative Turnout Rates by the Type of Elections

\begin{tabular}{lccc}
\hline \hline Type of Elections & $\mathrm{N}$ & Mean (\%) & Std. Dev. \\
\hline partisan contested & 1246 & 82.9 & 30.3 \\
partisan uncontested & 3481 & 63.5 & 22.6 \\
nonpartisan contested & 946 & 76.0 & 21.5 \\
nonpartisan uncontested & 1973 & 61.1 & 14.7 \\
retention & 3989 & 66.7 & 18.9 \\
\hline Total & 11635 & 67.3 & 22.1 \\
\hline
\end{tabular}

Note: Only general elections are included. All pairwise differences in turnout rates between election systems are statistically significant at 5\%-level. Arizona and Ohio, which hold partisan primaries, are excluded from nonpartisan elections in turnout calculation, even though party affiliation does not appear on the ballot. Wisconsin, which does not hold judicial elections together with other state elections, and Tennessee, which has general judicial elections with state primaries, are also excluded from the statistics. Uncontested second round races of nonpartisan elections are included in this table, for comparison with uncontested partisan general elections. 
TABLE 13

Voter Turnout and Newspaper Coverage (Congruence)

\begin{tabular}{llll}
\hline \hline Variable & \multicolumn{1}{c}{$(1)$} & \multicolumn{1}{c}{$(2)$} & \multicolumn{1}{c}{$(3)$} \\
\hline Congruence & $-0.052^{* * *}$ & 0.010 & -0.003 \\
& $(0.014)$ & $(0.014)$ & $(0.014)$ \\
Congruence* Nonpartisan & $0.097^{* * *}$ & $0.067^{* * *}$ & $0.079^{* * *}$ \\
& $(0.024)$ & $(0.019)$ & $(0.020)$ \\
Congruence*Retention & 0.021 & -0.021 & -0.005 \\
& $(0.028)$ & $(0.022)$ & $(0.018)$ \\
Nonpartisan & $-0.109^{* *}$ & $-0.063^{*}$ & $-0.085^{* *}$ \\
& $(0.043)$ & $(0.036)$ & $(0.039)$ \\
Retention & $0.040^{* *}$ & $0.075^{* * *}$ & $0.063^{* * *}$ \\
& $(0.017)$ & $(0.016)$ & $(0.016)$ \\
\hline State Fixed Effects & Yes & Yes & Yes \\
Control Variables & No & pop., & All \\
$R^{2}$ & 0.40 & 0.45 & 0.48 \\
No. obs & 9149 & 9149 & 9149 \\
\hline
\end{tabular}

Note: Standard errors are clustered at state-year level. ${ }^{* * *}$ : significant at $1 \%$-level. Control variables included are: population (log), density (log), demographic composition of the population (race, gender, ethnicity, age), income, education, and crime rates. 
TABLE 14

Judge Competence Ranking by the Chamber of Commerce

\begin{tabular}{ccccc}
\hline \hline Year & Appointed $^{\text {a }}$ & Retention & Nonpartisan & Partisan \\
\hline 2002 & 23.2 & 16.2 & 25.4 & 37.8 \\
2003 & 21.0 & 16.9 & 26.1 & 38.2 \\
2004 & 19.5 & 15.7 & 27.7 & 37.7 \\
2005 & 19.0 & 21.4 & 25.4 & 37.8 \\
2006 & 19.4 & 16.6 & 26.7 & 39.1 \\
2007 & 18.1 & 21.9 & 26.0 & 36.9 \\
2008 & 19.3 & 15.4 & 27.5 & 38.6 \\
2010 & 16.9 & 19.8 & 26.6 & 39.1 \\
\hline \# Obs & 11 & 9 & 21 & 9 \\
\hline
\end{tabular}

a The 'Appointed' category includes all the states with appointed judges regardless of whether they are life-tenured, re-appointed, or they face retention elections. There is no significant difference in rankings between sub-categories of the appointment system. 
TABLE 15

Judicial Malfeasance

\begin{tabular}{lcc}
\hline \hline & $\begin{array}{c}\text { Retention/ } \\
\text { Item }\end{array}$ & \\
\hline Criminal Findings & 11.1 & 18.6 \\
Serious Findings & 17.3 & 32.1 \\
Multiple Findings in One Case & 41.6 & 54.1 \\
Findings of Lack of Impartiality & 21.1 & 29.0 \\
Findings of Arrogance & 33.5 & 45.2 \\
Findings of Deceitfulness & 10.6 & 16.2 \\
Neglect of Duties or Incompetence & 16.6 & 10.7 \\
Findings of Improper Political Activity & 7.3 & 9.7 \\
Judges w/Multiple Disciplinary Cases & 8.5 & 8.6 \\
\hline Number of Observations & 331 & 290 \\
\hline
\end{tabular}


Table A.1: Competition in Partisan Elections by State - Primary Elections

\begin{tabular}{|c|c|c|c|c|c|c|c|c|c|c|}
\hline \multirow{4}{*}{ State } & \multirow{4}{*}{$\begin{array}{c}\text { Seats } \\
\text { up for } \\
\text { Election }\end{array}$} & \multicolumn{5}{|c|}{ Number of Races } & \multirow{3}{*}{\multicolumn{2}{|c|}{$\begin{array}{c}\text { Number of } \\
\text { Candidates in } \\
\text { Contested Elections }\end{array}$}} & \multirow{3}{*}{\multicolumn{2}{|c|}{$\begin{array}{c}\text { Winner's } \\
\text { Vote Share in } \\
\text { Contested Elections }\end{array}$}} \\
\hline & & \multirow[b]{3}{*}{ Total $^{*}$} & \multicolumn{2}{|c|}{ Democrat } & \multicolumn{2}{|c|}{ Republican } & & & & \\
\hline & & & \multirow{2}{*}{$\begin{array}{l}\text { UnCon- } \\
\text { tested }\end{array}$} & \multirow{2}{*}{$\begin{array}{l}\text { Con- } \\
\text { tested }\end{array}$} & \multirow{2}{*}{$\begin{array}{l}\text { Uncon- } \\
\text { tested }\end{array}$} & \multirow{2}{*}{$\begin{array}{l}\text { Con- } \\
\text { tested }\end{array}$} & & & & \\
\hline & & & & & & & Mean & Std Dev & Mean & Std Dev \\
\hline $\mathrm{AL}$ & 541 & 189 & 59 & 49 & 32 & 49 & 2.3 & 0.5 & 0.589 & 0.093 \\
\hline $\mathrm{AR}$ & 52 & 28 & 9 & 13 & 3 & 3 & 2.1 & 0.3 & 0.625 & 0.090 \\
\hline $\mathrm{AZ}$ & 49 & 58 & 28 & 6 & 22 & 2 & 2.4 & 0.7 & 0.593 & 0.190 \\
\hline IL & 969 & 1365 & 309 & 435 & 368 & 253 & 3.5 & 2.0 & 0.448 & 0.162 \\
\hline IN & 407 & 491 & 151 & 37 & 243 & 60 & 2.4 & 0.7 & 0.553 & 0.101 \\
\hline $\mathrm{KS}$ & 526 & 562 & 241 & 31 & 240 & 50 & 2.3 & 0.8 & 0.544 & 0.110 \\
\hline MD & 104 & 206 & 67 & 36 & 66 & 37 & 2.6 & 1.2 & 0.638 & 0.141 \\
\hline $\mathrm{MO}$ & 177 & 195 & 86 & 18 & 69 & 22 & 2.4 & 0.7 & 0.553 & 0.110 \\
\hline MS & 12 & 11 & 5 & 5 & 0 & 1 & 2.0 & 0.0 & 0.637 & 0.107 \\
\hline $\mathrm{NC}$ & 50 & 16 & 0 & 12 & 0 & 4 & 2.1 & 0.3 & 0.623 & 0.088 \\
\hline NM & 122 & 143 & 53 & 35 & 46 & 9 & 2.3 & 0.6 & 0.548 & 0.092 \\
\hline $\mathrm{OH}$ & 1565 & 2154 & 776 & 191 & 1046 & 141 & 2.6 & 1.2 & 0.548 & 0.144 \\
\hline $\mathrm{PA}$ & 97 & 188 & 11 & 84 & 23 & 70 & 3.2 & 1.5 & 0.496 & 0.132 \\
\hline $\mathrm{TX}$ & 2572 & 3122 & 1163 & 283 & 1352 & 324 & 2.2 & 0.6 & 0.591 & 0.094 \\
\hline WV & 193 & 228 & 111 & 57 & 50 & 10 & 2.3 & 0.6 & 0.563 & 0.105 \\
\hline Total & 7436 & 8956 & 3069 & 1292 & 3560 & 1035 & 2.8 & 1.4 & 0.529 & 0.145 \\
\hline
\end{tabular}

Note: For the number of candidates and winners' vote share, we report only the statistics of the elections with single winners, because statistics of the elections in multi-winner elections are not comparable to those of singlewinner elections. Arkansas used partisan elections until 2000, then switched to non-partisan elections. In Arizona, counties with populations of 250,000 or greater select state trial court judges through gubernatorial appointment and retention election, and all other counties use partisan primaries and non-partisan general elections. Indiana uses partisan elections with the following exceptions: Circuit Courts and Superior Courts in Vanderburg County and Superior Court in Allen County use non-partisan elections; and, Superior Courts in Lake and St. Joseph Counties use gubernatorial appointment and retention elections. In Kansas, 14 judicial districts use partisan elections, and the other 17 districts use gubernatorial appointment and retention elections. In Missouri, Jackson, Clay, Platte, and St. Louis counties use gubernatorial appointment and retention elections for state trial court judges, and all other use partisan elections. Gubernatorial appointment with retention elections are used for appellate and supreme courts. Mississippi used partisan elections until 1992. North Carolina used partisan elections for superior courts until 1998, and for appellate and supreme courts until 2004. New York, which uses partisan elections, is omitted from the table because it uses party conventions rather than primaries to make judicial nominations. The data on primary elections in Tennessee are unavailable.

Note* : The total number of races does not include the primaries of the third party. 
Table A.2: Competition in Partisan Elections by State - General Elections

\begin{tabular}{|c|c|c|c|c|c|c|c|c|}
\hline \multirow[t]{2}{*}{ State } & \multirow{2}{*}{$\begin{array}{c}\text { Seats } \\
\text { up for } \\
\text { Election }\end{array}$} & \multirow{2}{*}{$\begin{array}{c}\text { Total } \\
\text { Number } \\
\text { of Races }\end{array}$} & \multirow{2}{*}{$\begin{array}{l}\text { No. of } \\
\text { Uncon- } \\
\text { tested } \\
\text { Races }\end{array}$} & \multirow{2}{*}{$\begin{array}{l}\text { No. of } \\
\text { Con- } \\
\text { tested } \\
\text { Races }\end{array}$} & \multicolumn{2}{|c|}{$\begin{array}{c}\text { Number of } \\
\text { Candidates in } \\
\text { Contested Elections }\end{array}$} & \multicolumn{2}{|c|}{$\begin{array}{c}\text { Winner's } \\
\text { Vote Share in } \\
\text { Contested Elections }\end{array}$} \\
\hline & & & & & Mean & Std Dev & Mean & Std Dev \\
\hline $\mathrm{AL}$ & 541 & 533 & 391 & 142 & 2.0 & 0.0 & 0.552 & 0.066 \\
\hline $\mathrm{AR}$ & 52 & 32 & 16 & 16 & 2.0 & 0.0 & 0.602 & 0.074 \\
\hline IL & 969 & 962 & 562 & 400 & 2.0 & 0.1 & 0.595 & 0.069 \\
\hline IN & 407 & 406 & 307 & 99 & 2.0 & 0.1 & 0.573 & 0.063 \\
\hline $\mathrm{KS}$ & 526 & 522 & 449 & 73 & 2.0 & 0.0 & 0.563 & 0.056 \\
\hline $\mathrm{MO}$ & 177 & 174 & 135 & 39 & 2.0 & 0.2 & 0.576 & 0.088 \\
\hline MS & 12 & 11 & 8 & 3 & 2.0 & 0.0 & 0.613 & 0.078 \\
\hline $\mathrm{NC}$ & 50 & 44 & 11 & 33 & 2.0 & 0.0 & 0.535 & 0.040 \\
\hline NM & 122 & 118 & 63 & 55 & 2.0 & 0.2 & 0.557 & 0.045 \\
\hline NY & 201 & 201 & 40 & 161 & 2.1 & 0.3 & 0.589 & 0.087 \\
\hline PA & 97 & 97 & 37 & 60 & 2.1 & 0.2 & 0.559 & 0.038 \\
\hline $\mathrm{TN}$ & 180 & 180 & 134 & 46 & 2.4 & 0.8 & 0.578 & 0.130 \\
\hline TX & 2572 & 2547 & 1825 & 722 & 2.0 & 0.2 & 0.554 & 0.074 \\
\hline WV & 193 & 193 & 153 & 40 & 2.0 & 0.0 & 0.570 & 0.049 \\
\hline Total & 6099 & 6020 & 4131 & 1889 & 2.0 & 0.2 & 0.567 & 0.074 \\
\hline
\end{tabular}

Note: For number of candidates and winners' vote share in contested elections, we report only the statistics of the elections in single-member districts, because statistics of the elections in multi-member districts are not comparable to those of single-member districts. 
Table A.3: Competition in Non-Partisan Elections by State - First Round

\begin{tabular}{|c|c|c|c|c|c|c|c|}
\hline \multirow[b]{2}{*}{ State } & \multirow{2}{*}{$\begin{array}{c}\text { Total } \\
\text { Number } \\
\text { of Races }\end{array}$} & \multirow{2}{*}{$\begin{array}{l}\text { No. of } \\
\text { Uncon- } \\
\text { tested } \\
\text { Races }\end{array}$} & \multirow{2}{*}{$\begin{array}{l}\text { No. of } \\
\text { Con- } \\
\text { tested } \\
\text { Races }\end{array}$} & \multicolumn{2}{|c|}{$\begin{array}{c}\text { No. of Candidates } \\
\text { in Contested } \\
\text { Elections }\end{array}$} & \multicolumn{2}{|c|}{$\begin{array}{c}\text { Top Vote-getter's } \\
\text { Vote Share in } \\
\text { Contested Elections }\end{array}$} \\
\hline & & & & Mean & Std Dev & Mean & Std Dev \\
\hline $\mathrm{AR}$ & 109 & 41 & 68 & 2.3 & 0.7 & 0.569 & 0.089 \\
\hline $\mathrm{CA}$ & 377 & 52 & 325 & 2.8 & 1.3 & 0.584 & 0.132 \\
\hline FL & 1689 & 1505 & 184 & 3.2 & 0.9 & 0.453 & 0.116 \\
\hline GA & 804 & 660 & 144 & 2.6 & 1.2 & 0.589 & 0.117 \\
\hline ID & 182 & 164 & 18 & 2.3 & 0.5 & 0.581 & 0.074 \\
\hline IN & 29 & 24 & 5 & 2.8 & 0.8 & 0.526 & 0.110 \\
\hline KY & 361 & 232 & 129 & 2.4 & 0.9 & 0.557 & 0.099 \\
\hline LA & 812 & 568 & 244 & 2.8 & 1.1 & 0.550 & 0.115 \\
\hline MI & 504 & 349 & 155 & 3.3 & 1.7 & 0.527 & 0.135 \\
\hline $\mathrm{MN}$ & 741 & 639 & 102 & 2.9 & 2.8 & 0.581 & 0.119 \\
\hline MS & 111 & 58 & 53 & 2.4 & 0.8 & 0.568 & 0.096 \\
\hline MT & 154 & 128 & 26 & 2.9 & 1.3 & 0.523 & 0.124 \\
\hline $\mathrm{NC}$ & 172 & 101 & 71 & 2.7 & 1.2 & 0.544 & 0.127 \\
\hline $\mathrm{ND}$ & 168 & 146 & 22 & 2.7 & 1.2 & 0.561 & 0.143 \\
\hline $\mathrm{NV}$ & 181 & 88 & 93 & 3.3 & 1.5 & 0.538 & 0.142 \\
\hline OK & 571 & 348 & 223 & 2.5 & 0.9 & 0.571 & 0.102 \\
\hline OR & 703 & 602 & 101 & 2.9 & 1.3 & 0.545 & 0.125 \\
\hline $\mathrm{SD}$ & 83 & 59 & 24 & 2.4 & 0.8 & 0.560 & 0.130 \\
\hline WA & 493 & 296 & 197 & 2.6 & 1.0 & 0.565 & 0.110 \\
\hline WI & 1036 & 802 & 234 & 2.7 & 1.2 & 0.580 & 0.125 \\
\hline Total & 9280 & 6862 & 2418 & 2.8 & 1.3 & 0.560 & 0.122 \\
\hline
\end{tabular}

Note 1: For the number of candidates and winners' vote share in contested elections, we report only the statistics of the elections in single-member districts, because statistics of the elections in multi-member districts are not comparable to those of single-member districts.

Note 2: In Indiana, non-partisan election is used only in Vanderburgh and Allen County. All the nonpartisan elections in Indiana in this table were held in general elections. 
Table A.4: Competition in Non-Partisan Elections by State - Second Round

\begin{tabular}{|c|c|c|c|c|c|c|c|}
\hline \multirow[b]{2}{*}{ State } & \multirow{2}{*}{$\begin{array}{c}\text { Total } \\
\text { Number } \\
\text { of Races }\end{array}$} & \multirow{2}{*}{$\begin{array}{l}\text { No. of } \\
\text { Uncon- } \\
\text { tested } \\
\text { Races }\end{array}$} & \multirow{2}{*}{$\begin{array}{l}\text { No. of } \\
\text { Con- } \\
\text { tested } \\
\text { Races }\end{array}$} & \multicolumn{2}{|c|}{$\begin{array}{l}\text { No. of Candidates } \\
\text { in Contested } \\
\text { Elections }\end{array}$} & \multicolumn{2}{|c|}{$\begin{array}{c}\text { Winner's } \\
\text { Vote Share in } \\
\text { Contested Elections }\end{array}$} \\
\hline & & & & Mean & Std Dev & Mean & Std Dev \\
\hline $\mathrm{AR}$ & 9 & & 9 & 2.0 & 0.0 & 0.564 & 0.039 \\
\hline $\mathrm{AZ}$ & 56 & 47 & 9 & 2.8 & 1.6 & 0.554 & 0.100 \\
\hline $\mathrm{CA}$ & 105 & & 105 & 2.0 & 0.0 & 0.563 & 0.052 \\
\hline FL & 125 & & 125 & 2.0 & 0.0 & 0.558 & 0.045 \\
\hline GA & 36 & & 36 & 2.0 & 0.2 & 0.577 & 0.065 \\
\hline ID & 5 & & 5 & 2.0 & 0.0 & 0.552 & 0.026 \\
\hline KY & 23 & & 23 & 2.0 & 0.0 & 0.581 & 0.062 \\
\hline LA & 75 & & 75 & 2.0 & 0.0 & 0.569 & 0.093 \\
\hline MD & 119 & 112 & 7 & 2.0 & 0.0 & 0.615 & 0.052 \\
\hline MI & 70 & & 70 & 2.0 & 0.0 & 0.548 & 0.040 \\
\hline $\mathrm{MN}$ & 20 & & 20 & 2.0 & 0.0 & 0.584 & 0.068 \\
\hline MS & 4 & & 4 & 2.0 & 0.0 & 0.563 & 0.068 \\
\hline $\mathrm{MT}$ & 47 & & 47 & 2.0 & 0.0 & 0.586 & 0.069 \\
\hline $\mathrm{NC}$ & 22 & & 22 & 2.0 & 0.0 & 0.554 & 0.037 \\
\hline $\mathrm{ND}$ & 40 & & 40 & 2.0 & 0.0 & 0.592 & 0.068 \\
\hline NV & 57 & & 57 & 2.0 & 0.0 & 0.573 & 0.054 \\
\hline $\mathrm{OH}$ & 1564 & 908 & 656 & 2.1 & 0.3 & 0.592 & 0.081 \\
\hline OK & 57 & & 57 & 2.0 & 0.0 & 0.558 & 0.043 \\
\hline OR & 28 & & 28 & 2.0 & 0.0 & 0.559 & 0.044 \\
\hline $\mathrm{SD}$ & 7 & & 7 & 2.0 & 0.0 & 0.559 & 0.043 \\
\hline WA & 54 & & 54 & 2.0 & 0.0 & 0.563 & 0.045 \\
\hline WI & 96 & & 96 & 2.0 & 0.0 & 0.579 & 0.060 \\
\hline Total & 2619 & 1067 & 1552 & 2.0 & 0.2 & 0.578 & 0.070 \\
\hline
\end{tabular}

Note 1: For number of candidates and winners' vote share in contested elections, we report only the statistics of the elections in single-member districts, because statistics of the elections in multi-member districts are not comparable to those of single-member districts.

Note 2: Arizona has partisan primaries and non-partisan general elections in counties with population smaller than 250,000. The nonpartisan elections in Arizona in this table were all held in general elections after partisan primaries.

Note 3: The nonpartisan elections in Ohio and in Maryland in this table were all held in general elections after partisan primaries. 
Table A.5: Vote Share in Retention Elections by State

\begin{tabular}{|c|c|c|c|c|c|c|c|c|}
\hline \multirow[b]{2}{*}{ State } & \multirow[b]{2}{*}{$\begin{array}{c}\text { No. of } \\
\text { Elections }\end{array}$} & \multicolumn{7}{|c|}{ Shares of Yes-Votes } \\
\hline & & Mean & Std Dev & Min & $\begin{array}{c}\text { 10th } \\
\text { Percen } \\
\text {-tile }\end{array}$ & Median & $\begin{array}{c}\text { 90th } \\
\text { Percen- } \\
\text { tile }\end{array}$ & Max \\
\hline AK & 182 & 0.662 & 0.055 & 0.519 & 0.601 & 0.660 & 0.730 & 0.841 \\
\hline $\mathrm{AZ}$ & 549 & 0.721 & 0.060 & 0.537 & 0.632 & 0.726 & 0.802 & 0.831 \\
\hline $\mathrm{CA}$ & 300 & 0.695 & 0.061 & 0.519 & 0.611 & 0.707 & 0.763 & 0.801 \\
\hline $\mathrm{CO}$ & 380 & 0.709 & 0.058 & 0.378 & 0.635 & 0.721 & 0.770 & 0.822 \\
\hline FL & 360 & 0.698 & 0.051 & 0.531 & 0.631 & 0.706 & 0.761 & 0.810 \\
\hline IA & 791 & 0.746 & 0.054 & 0.376 & 0.683 & 0.756 & 0.800 & 0.852 \\
\hline IL & 1677 & 0.766 & 0.053 & 0.511 & 0.705 & 0.775 & 0.825 & 0.885 \\
\hline IN & 33 & 0.696 & 0.037 & 0.595 & 0.649 & 0.702 & 0.732 & 0.780 \\
\hline KS & 691 & 0.754 & 0.063 & 0.509 & 0.673 & 0.757 & 0.837 & 0.905 \\
\hline MD & 47 & 0.845 & 0.040 & 0.746 & 0.779 & 0.861 & 0.883 & 0.899 \\
\hline MO & 279 & 0.683 & 0.043 & 0.554 & 0.627 & 0.685 & 0.739 & 0.780 \\
\hline $\mathrm{MT}$ & 108 & 0.813 & 0.057 & 0.591 & 0.730 & 0.832 & 0.877 & 0.916 \\
\hline $\mathrm{NE}$ & 217 & 0.720 & 0.057 & 0.326 & 0.665 & 0.730 & 0.775 & 0.825 \\
\hline NM & 207 & 0.741 & 0.062 & 0.505 & 0.655 & 0.750 & 0.809 & 0.861 \\
\hline OK & 105 & 0.643 & 0.043 & 0.557 & 0.575 & 0.656 & 0.689 & 0.720 \\
\hline $\mathrm{PA}$ & 195 & 0.744 & 0.080 & 0.355 & 0.628 & 0.755 & 0.825 & 0.865 \\
\hline $\mathrm{SD}$ & 9 & 0.830 & 0.011 & 0.812 & 0.812 & 0.829 & 0.846 & 0.846 \\
\hline $\mathrm{TN}$ & 42 & 0.746 & 0.024 & 0.683 & 0.710 & 0.755 & 0.771 & 0.776 \\
\hline UT & 265 & 0.795 & 0.052 & 0.460 & 0.745 & 0.798 & 0.853 & 0.886 \\
\hline WY & 68 & 0.779 & 0.045 & 0.493 & 0.743 & 0.785 & 0.820 & 0.847 \\
\hline Total & 6505 & 0.739 & 0.067 & 0.326 & 0.646 & 0.747 & 0.817 & 0.916 \\
\hline
\end{tabular}

Note: Arizona, California, Florida, Oklahoma, and Tennessee use gubernatorial appointment and retention election for state appellate courts and supreme courts. In Montana, incumbent judges who are unopposed in the first round run for retention elections at the time of general elections. South Dakota uses gubernatorial appointment and retention election only for the state supreme court. 
Table A.6: Partisan Differences in Judicial Evaluations

\begin{tabular}{|c|c|c|c|c|c|}
\hline \multirow{2}{*}{ State } & \multirow{2}{*}{ Evaluating Body } & \multicolumn{4}{|c|}{ Average Score } \\
\hline & & Dem & Rep & Diff & P-val \\
\hline $\mathrm{AZ}$ & Arizona Commiss. on Judicial Performance Review & $\begin{array}{l}1.00 \\
(110)\end{array}$ & $\begin{array}{l}0.98 \\
(190)\end{array}$ & 0.02 & 0.19 \\
\hline $\mathrm{CO}$ & Colorado Commiss. on Judicial Performance & $\begin{array}{l}0.99 \\
(474)\end{array}$ & $\begin{array}{l}0.99 \\
(184)\end{array}$ & 0.00 & 0.77 \\
\hline IL & Average Across All Associations & $\begin{array}{l}0.75 \\
(2604)\end{array}$ & $\begin{array}{l}0.81 \\
(1439)\end{array}$ & -0.07 & 0.00 \\
\hline IA & Iowa State Bar Association & $\begin{array}{l}1.00 \\
(116)\end{array}$ & $\begin{array}{l}1.00 \\
(400)\end{array}$ & 0.01 & 0.45 \\
\hline $\mathrm{KS}$ & Kansas Commission on Judicial Performance & $\begin{array}{l}0.96 \\
(55)\end{array}$ & $\begin{array}{l}0.95 \\
(40)\end{array}$ & 0.01 & 0.75 \\
\hline $\mathrm{MO}$ & Missouri Bar Association & $\begin{array}{l}0.96 \\
(191)\end{array}$ & $\begin{array}{l}0.99 \\
(101)\end{array}$ & -0.03 & 0.13 \\
\hline $\mathrm{NE}$ & Nebraska State Bar Association & $\begin{array}{l}0.97 \\
(162)\end{array}$ & $\begin{array}{l}0.99 \\
(177)\end{array}$ & -0.03 & 0.08 \\
\hline NM & New Mexico Judicial Performance Eval. Commiss. & $\begin{array}{l}0.98 \\
(104)\end{array}$ & $\begin{array}{l}1.00 \\
(35)\end{array}$ & -0.02 & 0.41 \\
\hline NY & New York City Bar Association & $\begin{array}{l}0.94 \\
(68)\end{array}$ & $\begin{array}{l}0.54 \\
(56)\end{array}$ & 0.41 & 0.00 \\
\hline $\mathrm{OH}$ & Average Across All Associations & $\begin{array}{l}0.76 \\
(603)\end{array}$ & $\begin{array}{l}0.86 \\
(492)\end{array}$ & -0.10 & 0.00 \\
\hline $\mathrm{TX}$ & Average Across All Associations & $\begin{array}{l}0.72 \\
(621)\end{array}$ & $\begin{array}{l}0.81 \\
(769)\end{array}$ & -0.09 & 0.00 \\
\hline WY & Wyoming State Bar Association & $\begin{array}{l}0.94 \\
(48)\end{array}$ & $\begin{array}{l}0.92 \\
(24)\end{array}$ & 0.02 & 0.75 \\
\hline
\end{tabular}


Figure 1

Judicial Sub-circuits and Partisanship of Cook County, IL
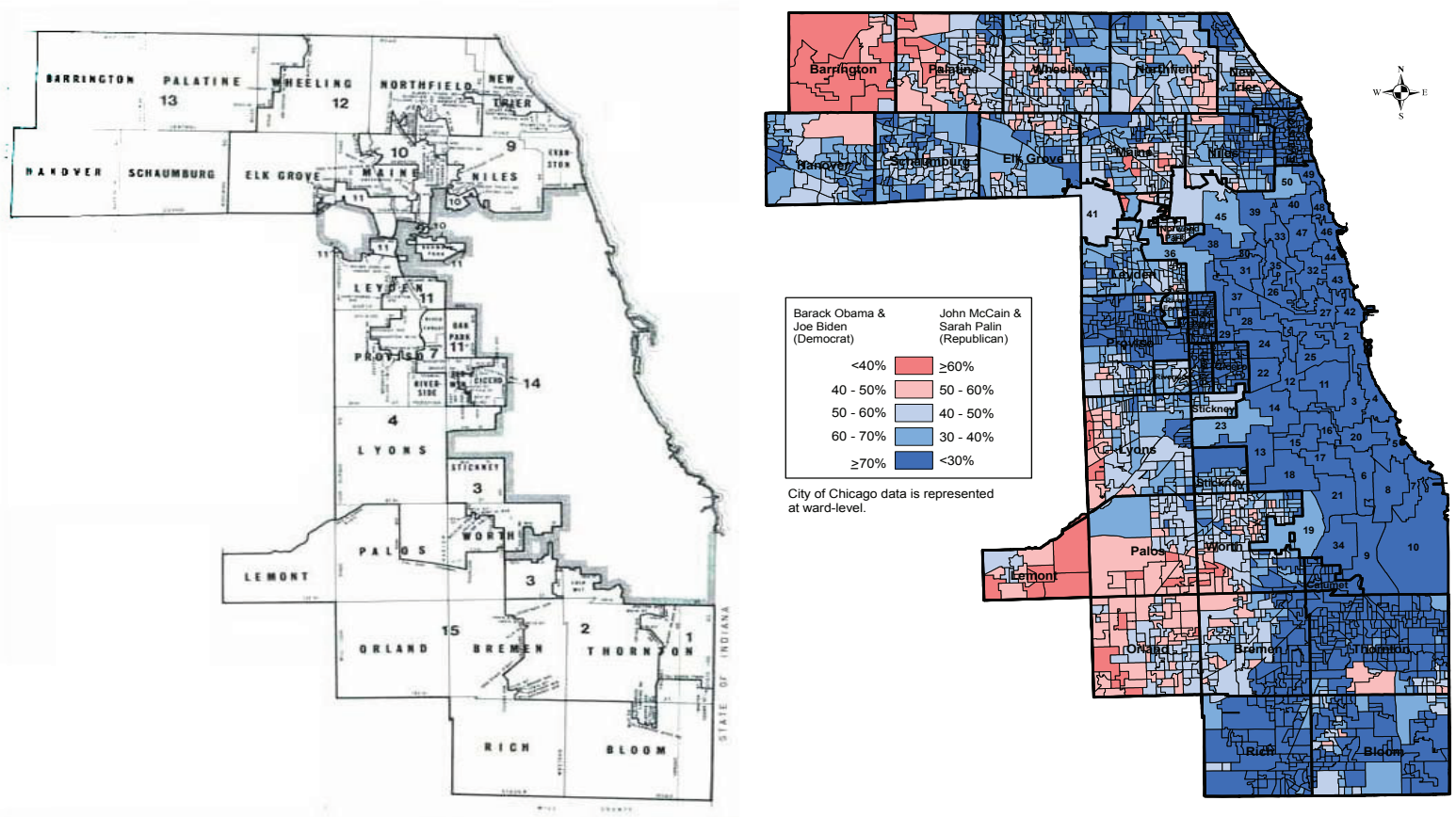
Figure 2

Example - High Congruence and Low Congruence

High Congruence Low Congruence

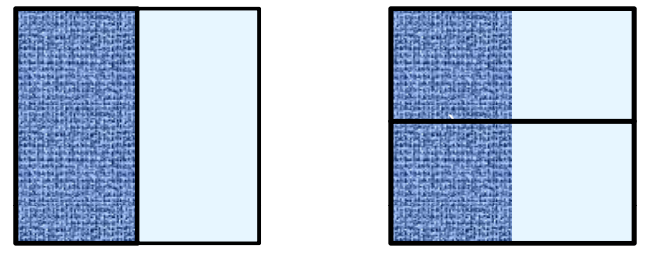

Circulation Area of Newspaper A

Circulation Area of Newspaper B

- Judicial District Boundary 